\title{
Hukuka Aykırı Delillerin Disiplin Soruşturmasında Kullanılması Sorunu
}

Dr. Bahattin ARAS*

Makalenin Geliş Tarihi: 06.11.2020 Kabul Tarihi: 30.06.2021

Bu makale hakem incelemesinden geçmiştir ve TÜBİTAK - ULAKBİM

Veri Tabanında indekslenmektedir.

DOI $\underline{10.30915 / a b d .978708}$

* Danısman/Freelance Editor. https://orcid.org/0000-0002-3551-7363 


\section{HUKUKA AYKIRI DELILLERIN DISIPLIN SORUŞTURMASINDA KULLANILMASI SORUNU}

\section{öz}

Ceza veya disiplin soruşturmasında maddi gerçeğin ortaya çıkarılması ancak hukuka uygun yöntemlerle elde edilmiş delillerle mümkündür. Maddi gerçeğin ortaya çıkarılması gerekçesiyle de olsa hukuka aykırı delillere dayanılamaz. Burada Anayasadan ve evrensel hukuk ilkelerinden kaynağını alan mutlak bir yasak vardır. Dolayısıyla somut olayın özellikleri, kamu yararının gerektirmesi gibi soyut ve içeriği kötüye kullanılabilecek, keyfi yorumlanabilecek gerekçelerle hukuka aykırı elde edilmiş delillerin disiplin soruşturmasında kullanılmasına istisna tanınması mümkün değildir. Ayrıca hukuk devleti ilkesinin ve adil yargılanma hakkının bir gereği olarak devletin kendisi hukuka aykırı delil elde etmesi söz konusu olmadığı gibi herhangi bir şekilde elde edilmiş hukuka aykırı delilleri meşrulaştırma veya yargısal sürece dahil etmesi de mümkün değildir.

\section{Anahtar Kelimeler:}

Hukuka Aykırı Delil

Disiplin Soruşturması

Delil

İspat

Yargılama 


\section{THE PROBLEM OF USING ILLEGAL EVIDENCES IN DISCIPLINARY INVESTIGATION}

\section{ABSTRACT}

Revealing the material fact is only possible with the evidence obtained by lawful methods in the criminal or disciplinary investigation. Even if it is on the grounds of revealing the material fact, illegal evidence cannot be relied on. Because there is an absolute prohibition here that derives from the Constitution and universal law principles. Therefore, it is not possible to give an exception to the use of evidence obtained against the law in the disciplinary investigation where the characteristics of the concrete event, the reasons for the public interest that can be misused, abused and arbitrarily interpreted. In addition, as a requirement of the principle of the rule of law and the right to a fair trial, it is not possible for the state neither to obtain unlawful evidence nor to legitimate any unlawful evidence or involve them with the judicial process.

\section{Keywords:}

\section{Illegal Evidence Disciplinary Investigation}




\section{GíRiş}

Ceza yargılamasında olduğu gibi disiplin soruşturmasında da maddi gerçeğin ortaya çıkarılması temel amaçtır. Maddi gerçeğin ortaya çıkarilması bakımından da Anayasa ve yasalar ile evrensel hukuk ilkelerinin belirlediği usule ve esasa ilişkin hükümlere riayet edilmesi gerekmektedir. Bu hükümler bir bütün olarak hukuka uygunluğun ve meşruluğun gerekçelerini oluşturmaktadırlar. Zira hukuki öngörülebilirlik, belirlilik ve kanunilik ilkelerinin bir gereği olarak soruşturma usulüne dair belirlenmiş olan hükümler keyfiliğin önündeki temel güvencelerdir.

Disiplin soruşturmaları bakımından usuli hükümler önemli olduğu kadar esasa ilişkin hususlar da önem arz etmektedir. Esas bakımından önemli olan konu ise iddiaların ispatı ve delillendirilmesidir. Bu noktada disiplin cezasının verilebilmesi için elde edilen delillerin maddi gerçeği ortaya çıkarmadaki gücü önemli olmakla birlikte, delillerin nasıl elde edildikleri yani elde edilme usulleri de önemlidir. Hukuka aykırı bir şekilde elde edilen delillerin ceza yargılamasında kullanılamayacağına ilişkin pozitif hukuk kuralları bulunduğundan ceza yargılamasında bu delillerin kullanılamayacağı konusunda herhangi bir tereddüt bulunmamaktadır. Ancak disiplin hukukunda, hukuka aykırı yöntemlerle elde edilmiş olan delillerin kullanılıp kullanılamayacağı hususunda açık bir pozitif hukuk kuralı bulunmadığından bahisle bu konuda uygulama, öğreti ve mahkeme kararlarında farkl11 lklar bulunmaktadır. ${ }^{[1]}$

Disiplin cezası bir yargılama faaliyeti neticesinde verilmekten ziyade idari makamların gerçekleştirdiği idari tasarruflar neticesinde verilmektedir. Ancak idare, disiplin soruşturması ve disiplin cezası verme işlemi sırasında yargı benzeri bir faaliyet yürüttüğünden disiplin cezası verme işlemi sürecinde mümkün olduğu kadar yargilamaya hakim olan ilkelere uygun hareket etmek zorundadır. Adil yargılanma hakkı da disiplin hukukunda kabul edilmesi gereken ilkelerden bir tanesi olduğundan hukuka aykırı elde edilmiş delillerin kabul edilmesi, adil yargılanma hakkına zarar vereceğinden disiplin soruşturması sürecinde kullanılmaması gerektiği gibi bu tip delillerin kullanıldığının idari işlemin iptali için açılan davada anlaşıması halinde idari yargı merciinin bu nedenle disiplin işleminin hukuka aykırı olarak verildiğine karar vermesi gerekir. ${ }^{[2]}$

[1] GÜNDÜZ, Fatma Ebru, "Hukuka Aykır Elde Edilmiş Delillerin Disiplin Hukukunda Kullanılması", Yıldırım Beyazıt Hukuk Dergisi, Y.4, S. 2019/1, s.91

[2] GÜNDÜZ, s.108 


\section{Dr. Bahattin ARAS}

Mevcut çalışmada disiplin soruşturmalarında hukuka aykırı delillerin kullanılmasından kaynaklı yaşanan sorunlar ve oluşan hak ihlalleri Avrupa İnsan Hakları Mahkemesi ve Anayasa Mahkemesi kararlarr ${ }^{[3]}$ ile Danıştay uygulamaları ışı̆̆ında değerlendirilecektir.

\section{I-) YARGILAMA HUKUKUNDA HUKUKA AYKIRI DELIL SORU- NU}

\section{A-) HUKUKA AYKIRI DELIL KAVRAMI}

Ceza yargılamasının temel amacı olan maddi gerçeğin ortaya çıkarılması sürecinde kullanılan vasıtalar "delil” olarak tanımlanmaktadır. Gerçeğin ortaya çıkarılmasında, kullanılan delillerin gücü kadar delillerin nasıl elde edildiği önem arz ettiğinden maddi gerçeğe ancak hukuk kuralları çerçevesinde hukuka uygun yöntemlerle elde edilmiş delillerle ulaşılması gerekir. Burada maddi gerçeğin ortaya çıkarılması adına temel haklardan ve adil yargılamadan vazgeçilmesi gibi bir durum söz konusu değildir. Maddi gerçeğin ortaya çıkarılmasında kamunun menfaatinin gözetilmesi kadar suçlanan kişinin de temel haklarının korunması esastır. ${ }^{[4]}$ Zira yargılamada hukuka aykırı yöntemlerle elde edilen delillerin esas alınması, hakkın kötüye kullanılmasına sebep olabileceği gibi, özel hayatın ve haberleşmenin gizliliği, konut dokunulmazlığı gibi hak ve hürriyetlere de zarar verebilecektir. ${ }^{[5]}$ Görüldüğ̈̈ üzere hukuka aykırı delillerin insan hakları ihlallerine hizmet etmesi nedeniyle kullanılması yasaktır.

Hukukun belli şekillerde yapılmasını emrettiği işlemlere aykırı olarak vücut bulan bulgular hukuka aykırı nitelik kazanacağından, bu suretle elde edilen deliller de hukuka aykırı delil olarak kabul edilecektir. ${ }^{[6]}$ Delillerin

[3] Çalışmamızda atıf yapılan AİHM kararlarının orijinal metnine "https://hudoc. echr.coe.int/eng\#\{\%22documentcollectionid 2\%22:[\%22GRANDCHAMBER \% 22,\%22CHA MBER\%22]\}"; Anayasa Mahkemesi kararlarının orijinal metnine "https://kararlarbilgibankasi.anayasa.gov.tr/" adresinden dosya adını yazmak suretiyle ulaşabilirsiniz. Bu nedenle atıf yapılan her bir karar bakımından bu sayfalara tekraren atıf yapılmamıştır.

[4] GÜNDÜZ, s.92; ÇINAR, Ali Rıza, "Hukuka Aykırı Kanıtlar ”, Türkiye Barolar Birliği Dergisi, Y. 2004, S. 55, s.32-33; AYDIN, Devrim, Ceza Muhakemesinde Deliller, Ankara 2015, Yetkin Yayınları, s.16

[5] ERMAN, Sahir, Hukuka Aykırı Deliller, İstanbul Barosu Yayınları, İstanbul 1995, s.222; GÜNDÜZ, s.92

[6] YAYLAK, Cihan, İdari Yargılama Usulünde Hukuka Aykırı Delillerin Değerlendirilmesi, On İki Levha Yayıncılık, İstanbul 2018, s. 8; Fİ̧ ÜSTÜN, Gül, “Disiplin 
hukuka aykırılığı konusu, insan haklarını koruma, delil elde etme ve kullanma bakımından belirlenen kriterler çerçevesinde ele alınmaktadır. Delil yasakları olarak da adlandırılan bu kriterlerin temel amacı aslında kolluğu disiplin altına sokmak ve temek hak ve hürriyetleri güvence altına almak$\operatorname{tır}^{[7]}$. Dolayısıyla soruşturma sürecinde, kişinin aydınlatılması yükümlülügünün ihlal edilmesi, aldatma, cebir, tehdit gibi yöntemlerle yasak sorgu ve ifade yöntemlerinin kullanılması, izinsiz veya mahkeme kararı olmaksızın iletişimin dinlenmesi, gizli görüntü ve ses kaydı alınması, bilgisayarlarının izinsiz ve yargı kararı olmaksızın aranması, kopyalanması veya el konulma suretiyle bilgi ve belge ele geçirilmesi veyahut iş yeri veya konutunun izinsiz aranması gibi yöntemlerle elde edilen deliller hukuka aykırı delil olarak kabul edilmektedir. ${ }^{[8]}$

Bu bakımdan ceza yargılamasında hukuka uygun yöntemlerle delil elde edilmesi ve yargılamanın hukuka uygun elde edilmiş delillere dayandırılması hukuk devletinin temel ve vazgeçilmez ilkelerindendir. Devlet adına yargılama yapma ve delil toplamakla görevlendirilmiş olan yargılama makamları, hukuka uygun yöntemlerle elde edilme imkanı bulunan bir delili yasadışı yöntemlerle elde etme yoluna gidemez. Zira hukuka uygun elde edilmesi mümkün delil, hukuka aykırı yöntemlerle elde edildiğinde yasak delil haline gelecektir. Dolayısıyla yasak delil haline gelmiş olan delilden hareketle elde edilecek yeni delillerin de ceza yargilamasında kullanilması mümkün değildir. Çünkü "Zehirli ağacın meyvesi de zehirlidir." prensibi uyarınca hukuka aykırı elde edilmiş olan delillerin "hukuka/kanuna karşı hile kullanmak suretiyle" meşru/hukuki bir delil vasfı kazanması mümkün değildir. ${ }^{[9]}$

Hukuk devletinin delillerin hukukiliği/yasallığı ilkesi olarak ifade edilebilecek bu ilkesi Anayasa'nın 38. maddesinin altıncı fikrasında da açık-

Soruşturmalarında Hukuka Aykırı Deliller”, Marmara Üniversitesi Hukuk Fakültesi Hukuk Araştırmaları Dergisi, Y.2018, C.24, S.1, s.19

[7] ŞAHİN, Cumhur, GÖKTÜRK, Neslihan, Ceza Muhakemesi Hukuku II, 11. Baskı, Seçkin Yayınları, Ankara 2021, s.35; ÖZBEK, Veli Özer/ DOĞAN, Koray, BACAKSIZ, Pınar, Ceza Muhakemesi Hukuku, 8. Baskı, Seçkin Yayınları, Ankara 2020, s.691

[8] CENTEL, Nur/ ZAFER, Hamide, Ceza Muhakemesi Hukuku, İstanbul, 2020, s. 265; ÖZTÜRK, Bahri, Nazari ve Uygulamalı Ceza Muhakemesi Hukuku, Ankara 2020, s. 417-418; FIŞ ÜSTÜN, s.19; GÖKPINAR, Mahmut, Disiplin Hukukunda Yasak Hukuka Aykırı Deliller, Disiplin Suçu Teorisi, İstanbul 2011, s.68 


\section{Dr. Bahattin ARAS}

ça hükme bağlanmıştır. Anayasal düzenlemeye göre kanuna aykırı olarak elde edilmiş bulgular delil olarak kabul edilemeyecektir. Anayasal hükme paralel olarak 5271 sayılı Ceza Muhakemesi Kanunu'nun 206/2-a maddesinde, kanuna aykırı elde edilmiş delilin reddedileceği; 217/2 maddesinde, yüklenen suçun hukuka uygun elde edilmiş her türlü delil ile ispat edilebileceği; 230/1-a maddesinde, reddedilen delillerin gösterilmesinden bahsedildikten sonra hukuka aykırı elde edilmiş delillerin ayrıca ve açıkça gösterilmesi gerektiği; 289/1 -i maddesinde ise, hükmün hukuka aykırı yöntemlerle elde edilmiş delile dayanmasının, kesin hukuka aykırılık sebebi olarak kabul edileceği hüküm altına alınmıştır.

Diğer taraftan hukuka aykırılık, kanuna aykırılıktan daha geniş bir içeriğe sahip olduğu için delillerin elde edilmesine ilişkin olarak da hukuka aykırılık kavramının kullanılması daha yerinde olacaktır. Bu noktada Anayasa Mahkemesi de bir kararında hukuka aykırı elde edilmiş delillerdeki hukuka aykırılık ifadesinin, pozitif hukuk kurallarından daha geniş bir içeriğe sahip olduğunu ve tüm pozitif hukuk kuralları ile birlikte hukukun kabul edilmiş evrensel ilkelerine aykırılığı da içerdiğini; bu anlamıyla "hukuka aykırı şekilde elde edilen delillerin", "yasal olmayan yöntemlerle elde edilen deliller" kavramından yani "yasadışılıktan” da geniş bir içeriğe sahip olduğunu belirtmiştir.

\section{B-) HUKUKA AYKIRI DELILLERIN UZAK ETKISI}

Yukarıda da izah edildiği üzere hukuka aykırı yöntemlerle elde edilmiş olan delillerin yargılamada kullanılması yasaktır. Bu noktada yasak deliller vasitasıyla elde edilen delillerin durumu gündeme gelmektedir. Bu noktada yasak delillere ilişkin "Zehirli ağacın meyvesi de zehirlidir" ilkesinden hareketle sonuca gidilmesi gerekir. Buna göre zehirli ağacın meyvesi olan yasak delillerden hareketle elde edilecek "türev" deliller de zehirli/yasak olduğundan bunların kullanılması mümkün değildir. ${ }^{[10]}$ Zira bu şekilde davranılmadığı takdirde temel hak ve hürriyetlere hukuksuz bir şekilde müdahale yolu açılacaktır. Bu aslında Anayasa ve kanunlara karşı hile kullanmak suretiyle temel mevzuat hükümlerinin ve belirlenen esasların bertaraf edilmesidir. Şöyle ki, kişi hakkında iletişimin denetlenmesi kararı alınmadan aylarca yapılacak dinlemelerden elde edilen verilerin bir harddisk, flash bellek ya da CD'ye kaydedilip daha sonra bu harddisk,

[10] ÖZTÜRK, s.417-418; ŞAHİ/GÖKTÜRK, s.35; ÖZER/DOĞAN/BACAKSIZ, s.694-695 
flash bellek yada CD'ye ilişkin olarak CMK'nın 134. maddesi kapsamında karar alınmasının nasıl bir "yargısal hile olacağı" ve hukuken kabul edilebilirliğinin bulunmadığı ortadadır.

$\mathrm{Bu}$ husus Anayasa Mahkemesi'nin emekli bir Yargıtay Daire Başkanı hakkında Yüce Divan sıfatıyla vermiş olduğu 2011/1 Esas, 2012/1 Karar ve 19.12.2012 Tarihli kararında özellikle ele alınmıştır. Mahkeme kararında "Telekomünikasyon yoluyla yapılan iletişimin denetlenmesi, CMK'nın 135. maddesinde düzenlenmiştir. Bu maddede belirlenen esas ve usuller dtşında hiç kimse, bir başkasının telekomünikasyon yoluyla iletişimini dinleyemez ve kayda alamaz. Aksi halde başka bir hususa bakılmaksızın elde edilen kayıtlar hukuka aykırı olur, sorusturma ve kovusturmalarda kullanılamaz." şeklinde tespitini ortaya koyduktan ve hukuka aykırı olarak uygulanan iletişimin denetlenmesi ve teknik araçlarla izleme tedbirleri sonucu elde edilen delillerin hükme esas alınmasının mümkün olmadığını belirttikten sonra yargılamada bu hukuka aykırı tedbirlerin uygulanmasında görev almış olan emniyet görevlilerinin tanık olarak dinlenmiş olmasının da "hukuka aykırı" delil kapsamında değerlendirilmesi gerektiğine ve isnat edilen eyleme ilişkin delil değerlendirmesinin de ilgili tedbirlerden elde edilen deliller dışında kalan diğer deliller dikkate alınmak suretiyle yapılması gerektiğine hükmetmiştir.

Yukarıda da izah edildiği üzere Anayasảnın 38. maddesi gereğince hukuka aykırı yöntemlerle elde edilmiş olan delillerin ceza soruşturma ve kovuşturmasında kullanılması mümkün değildir. Bu noktada öğretide ve uygulamada tartışılan bir başka konu da hukuka aykırı delillerin uzak etkisi sorunu olarak tanımlanan, hukuka aykırı bir delilden hareketle elde edilen delillerin yani türev delillerin nasıl bir işleme tabi tutulacağı hususudur. Kolluğu disiplin altına alma anlayışı çerçevesinde Amerikan Federal Yüksek Mahkemesi 1920 tarihli kararı ile söz konusu içtihadını geliştirip yalnızca hukuka aykırı elde edilmiş delilleri değil bunlardan hareketle elde edilen delillerin de hukuka aykırı olduğunu kabul etmiştir. ${ }^{[1]}$ Öğretide suç oluşturan eylemlerle elde edilen deliller bakımdan uzak etkinin ve değerlendirme yasağının kabul edilmesi gerektiği ifade edilmektedir. ${ }^{[12]}$

Bu bağlamda hukuk devletinde hukuksuzluk hiçbir gerekçeyle kabul

[11] AKYÜREK, Güçlü, “Ceza Yargzlamasında Hukuka Aykırı Delillerin Değerlendirilmesi Sorunu”, Türkiye Barolar Birliği Dergisi, Y. 2012, S.101, s.72-73

[12] YENISEY, Feridun/ NUHOĞLU. Ayşe, Ceza Muhakemesi Hukuku. İstanbul 2020, s.556; ÖZTÜRK, s.417-418 


\section{Dr. Bahattin ARAS}

edilmemeli ve kişilere "hukuku dolanma" olanağı tanınmamalıdır. Hukuka aykırı deliller geçersizken bu delil kullanılarak elde edilecek delilin hukuka uygun sayılması kanunu dolanma ve kanuna karşı bir hile olacaktır. Aynı şekilde bu tarz bir yaklaşım "zehirli ağacın meyvesi de zehirlidir" ilkesine aykırı olarak zehirli ağacın meyvesine meşruiyet kazandırma anlamına gelecektir. Dolayısıyla uzak etki bakımından da hukuka aykırı delillerden hareketle elde edilen delillerin de mutlak reddi gerekmektedir. ${ }^{[13]}$

\section{II-) DISIPLIN SORUŞTURMALARINDA HUKUKA AYKIRI DELILLERIN KULLANILMASI SORUNU}

\section{A-) DisiPLIN SORUŞTURMALARINDA HUKUKA AYKIRI DELILLER}

\section{1-) Anayasa'nın 38/6. Maddesinin Disiplin Soruşturmasını da Kapsaması}

Ceza hukukunun amacı kamu düzeni ve toplumu savunmak olmasına karşın, disiplin hukukunun amacı hizmetin iyi işlemesine yöneliktir. ${ }^{[14]}$ Genel kamu düzeni yerine, dar ve kısmi düzenleri konu alan disiplin hukuku, dar ve kısmi düzenlerin hizmetlerini yerine getirebilmesi ve sağlıklı işleyebilmesi için kişilerin görevlerini daha iyi yapması, daha verimli olmas1, kanunlara uyması, amirlerinin vermiş olduğu emirleri yerine getirmesi ve hizmetin aksamadan işlemesi bakımından bir kısım kural ve yaptırımlar öngörmektedir ${ }^{[15]}$. İşte disiplin soruşturması, bozulduğu varsayılan kısmi idari düzenin yeniden tesis edilmesi için disiplin suçuna konu eylemin cezalandırılması amacıyla yapılan, kendine özgü işleyiş ve özelliklere sahip olan bir inceleme ve araştırma faaliyetini ifade etmektedir. ${ }^{[16]}$

[13] CENTEL/ZAFER, s.798; AKYÜREK, s.79

[14] PINAR, İbrahim, Açıklamalı-İçtihatlı Memur Suçlarında İdari Soruşturma, Ankara 1987, s.308-309

[15] CEM, Cemil, "Disiplin ve Disiplin Hukuku”, Ankara Barosu Dergisi, Y.1969, S.5, s.822; ÇAKMAK, Seyfullah, "İletişimin Denetlenmesi Koruma Tedbiri Çerçevesinde Elde Edilen Tesadüfi Delillerin Disiplin Sorușturmasında Kullanılması", Terazi Hukuk Dergisi, Y.2010, C.5, S.48, s.71; İPEK, Ali İhsan, "İletişimin Denetlenmesi Yoluyla Elde Edilen Delillerin Disiplin Hukukuna Etkisi”, TAAD, Y.2, Ekim 2011, C.1, S.7, s.239; SANCAKDAR, Oğuz/TEPE, İlker, "Alman Federal Disiplin Kanunu ve İdari Disiplin Soruşturmalarmın Temel Esasları", İstanbul Üniversitesi Hukuk Fakültesi Mecmuası, Y.2011, C.69, S.1-2, s.256; CANOĞLU, Veysel Candan, "Disiplin Soruşturmasında Delil ve İspat" Türkiye Barolar Birliği Dergisi, Y.2018, s.138, s.232

[16] CANOĞLU, s.234 
Diğer taraftan disiplin soruşturması, ihbar ve şikâyetin yanı sıra başka idari mercilerce yapılan bildirim, doğrudan öğrenme, basın yoluyla öğrenme, teftiş ve inceleme sırasında öğrenme gibi çeşitli şekillerde eylemin öğrenilmesi üzerine verilen bir soruşturma emri ile başlamaktadır. İhbar veya şikâyetin işleme konulabilmesine ilişkin özel bir düzenleme bulunmayan hallerde disiplin amirinin re'sen harekete geçerek soruşturmayı başlatması ve eksiklikleri gidermesi lazımdır. ${ }^{[17]}$

Disiplin soruşturmasını gerektiren eylemin yetkili merci tarafından öğrenilmesi üzerine, doğrudan disiplin cezası verme yasağına göre, ceza verilebilmesi için soruşturmaya başlanması bir gerekliliktir. Soruşturmaya başlandıktan sonra, görevlendirilen soruşturmacı vasıtasıyla soruşturulan ile tanıkların ifadeleri alınmakta, deliller toplanmakta ve diğer gerekli işlemler yapıldıktan sonra hazırlanan soruşturma raporu üzerine kamu görevlisi hakkında karar verme aşamasına geçilmektedir. Disiplin cezasına karar verme yetkisi, soruşturmayı başlatma yetkisinden farklı olduğu için, rütbe ve kıdem gibi unsurlardan ziyade mevzuatta belirtilen kişi, kurul veya makam tarafindan bu disiplin cezası verme yetkisi kullanılacaktır. ${ }^{[18]}$

Kamu görevlisi hakkında disiplin soruşturması yürüten amir veya görevlendirilen soruşturmacı; soruşturma konusuyla sınırlı olmak üzere her türlü evrakı incelemeye, ilgili kurumlardan ve kişilerden bilgi ve belge almaya, tanık dinlemeye, mahallinde keşif yapmaya, hakkında soruşturma yapılan memurun savunmasını almaya, soruşturma raporu düzenlemeye yetkili konumdadır. Bununla birlikte, soruşturmacıya tanınan bu yetkilerin kullanımı veya soruşturma raporunun tesisi sırasında yapılan değerlendirmelerde bazı hatalar ve hukuka aykırılıklar meydana gelmektedir. Bu muhtemel hukuka aykırılıklardan biri de hukuka aykırı delil elde edilmesi ve elde edilen hukuka aykırı delillerin disiplin kararında kullanılmasıdır. ${ }^{[1]]}$

Yukarıda ilgili kısımlarda da vurgulandığı üzere ceza soruşturması ile disiplin soruşturması bağımsız olmakla beraber, ceza hukukuna hakim olan ilkelerin disiplin soruşturmalarında da geçerli olduğu kabul edilmektedir. ${ }^{[20]} \mathrm{Bu}$ kapsamda Anayasa Mahkemesi de "... Genel olarak disiplin cezaları kamu görevi ile ilgili bir ceza türü olarak benimsenmektedir. Anayasa’nın

[17] PINAR, s.323; CANOĞLU, s.238

[18] CANOĞLU, s.240

[19] FIŞ ÜSTÜN, s. 18

[20] GÜNDÜZ, s.95-96 


\section{Dr. Bahattin ARAS}

38. maddesinde idari ve adli cezalar arasinda bir ayrum yapılmamıs, ayruca ceza yerine geçen güvenlik önlemleri de madde kapsamına alınmıstır. Buna göre, disiplin cezalar Anayasa’nın 38. maddesi kapsamındadır... . '\{21] demek suretiyle Anayasa'nın "Suç ve cezalara ilişkin esaslar" başlıklı 38. maddesinin hem idari hem de adli cezaları kapsayan bir düzenleme olduğunu kabul etmiştir. Benzer şekilde Danıştay da istikrar kazanmış kararlarında ceza yargılamasına hakim olan ilkelerin disiplin hukukunda da geçerli olduğunu dile getirmiştir. ${ }^{[22]}$

Ceza muhakemesi hukukunda delillerin elde edilmesi temel hak ve hürriyetlere müdahale niteliği taşıdığı için delillerin nasıl elde edilebileceğine ilişkin usul ile hukuka aykırı delillerin kullanılması yasağına ilişkin yukarıda izah edildiği gibi katı yasal hükümler bulunmaktadır. Buna karşılık disiplin hukukunda ise ceza yargılamasındaki gibi delillerin elde edilme yöntemlerine ilişkin açık pozitif hukuk kuralları bulunmamaktadır. Bu noktada evrensel hukuk ilkeleri ile yüksek mahkemelerin disiplin hukukunda da uygulanacağını kabul ettiği ceza yargılamasının ilkelerine göre sonuca gidilmelidir.

Diğer taraftan öğretide, Anayasa’nın 38/6. maddesinin bir gereği olarak hukuka aykırı delillerin disiplin hukukunda kullanılamayacağı; zira Anayasa’ nın 38/6 maddesindeki hükmün sadece ceza yargılamasına ilişkin olmayıp, hukukun tüm alanları için geçerli bir ilke olduğu dile getirilmektedir. ${ }^{[23]}$ Delil, hukuka aykırı yöntemler ile elde edilmiş ise hangi hukuk dalında kullanıldığı önemli değildir. ${ }^{[24]}$ Hukuka aykırı elde edilmiş deliller ile hukuka uygun bir sonuç elde etmek mümkün değildir. Bu noktada her ne kadar Anayasa’nın madde başlığı "Suç ve cezalara ilişkin esaslar" ise

[21] AYM, 1990/12 E., 1991/7 K., 04.04.1991. T.

[22] “... Disiplin hukuku, cezalandırılma ilkeleri açısından ceza hukuku ile benzer özellikler taşımakta olup, kişilerin disiplin cezası ile cezalandırılabilmeleri için suç olarak belirlenmiş olan tutum ya da davranışın ilgilisi tarafından işlenmiş olduğunun kesin ve şüpheye yer bırakmayacak şekilde saptanması ve maddi gerçeğin tüm boyutlarıyla ortaya konması gerekmektedir. Ayrıca evrensel ceza hukuku ile Türk Ceza Kanunu'nda yer alan "şüpheden sanık yararlanır" ilkesi disiplin hukukunda da uygulama alanı bulmaktadır. (Danıstay 12.D., 2016/7260 E., 2017/2823 K., 30.05.2017 T.)

[23] AYDIN, s.224

[24] GÜNDÜZ, S.103; AKYILMAZ, Bahtiyar, "Anayasal Esaslar Çerçevesinde Kamu Personeli Disiplin Hukuku ve Uygulamadaki Sorunlar”, Gazi Üniversitesi Hukuk Fakültesi Dergisi, Y. 2002, C. 6, S. 1-2, s.241 
de bu sonucu değiştirmeyecektir. Zira Anayasa’nın 176/2. maddesindeki madde başlıklarının Anayasa metninden sayılmayacağına ilişkin düzenleme karşısında, 38. maddenin madde başlı̆̆ının "Suç ve cezalara ilişkin genel esaslar" şeklinde olması da bu maddede yer olan temel ilkelerin uygulanma alanının, sadece ceza yargısı ile sınırlı olduğu şeklinde yorumlanamaz. ${ }^{[25]}$ Anayasa Mahkemesi de bu doğrultuda değerlendirme yapmaktadır.

Öte yandan Anayasa'nın 38/6. maddesinde "Kanuna aykır olarak elde edilmiş bulgular "ifadesi yalnızca soruşturma ve kovuşturma organlarının hukuka aykırı olarak elde ettiği delilleri değil aynı zamanda özel kişiler tarafından elde edilen hukuka aykırı delilleri de kapsamaktadır. Dolayısıyla özel kişiler tarafından elde edilen hukuka aykırı delillerin soruşturma ve kovuşturma organları tarafından kullanılması mümkün değildir. Delil yasaklarının asıl amacı temel insan hak ve özgürlüklerini korumak olduğundan ve burada anayasal haklara ağır bir müdahale söz konusu olduğundan özel kişiler tarafından hukuka aykırı bir şekilde elde edilen deliller de delil yasakları kapsamındadır. Bu kapsamda kişinin gizlice alınan ses kaydı ya da bir kişinin hatıra defterinden aktarılan ve özel hayatını ilgilendiren bir bilgi kişi aleyhinde delil olarak kullanılamaz. Ayrıca Anayasa Mahkemesi'nin de ifade ettiği üzere özel kişiler tarafından elde edilen bu tür delillerin hükme esas alınmasının mafya oluşumlarını teşvik edeceği unutulmamalıdır. ${ }^{[26]}$

[25] TANRIVER, Süha, "Türk Medeni Usul Hukuku Bağlamında Hukuka Aykırı Yollardan Elde Edilen Delillerin Irdelenmesi”, Türkiye Barolar Birliği Dergisi, Y.2006, S.65, s.371

[26] “...Ceza Muhakemeleri Usulü Kanunu’nun 254. maddesinin ikinci fikrası dikkatle okunduğunda, bu fikrada hukuka aykırı olarak elde edilen deliller bakımından sadece soruşturma ve kovuşturma organlarının zikredildiği görülmektedir. Acaba özel kişiler tarafından elde edilen hukuka aykırı deliller soruşturma ve kovuşturma organları tarafından mahkemeye sunulursa ne olacaktır' ? Kanunda yasak delil yöntemleri kovuşturma makamları için öngörülmüştür. Ancak anayasal haklara ağır bir müdahale söz konusuysa özel kişiler tarafından hukuka aykırı bir şekilde elde edilen delillerin de delil yasakları kapsamına girmesi gerekir. Çünkü, delil yasaklarının asıl amacı temel insan hak ve özgürlüklerini korumaktır. Nitekim, Federal Alman Yargıtay’ı bir özel kişinin sanığın sözlerini gizlice banda alması halinde bu delilin değerlendirilmeye alınmayacağına karar vermiştir. Federal Almanyàda ayrıca gizlice banda alınan ya da bir kişinin hatıra defterinden aktarılan ve hayatın mahrem alanını ilgilendiren bir malumatın değerlendirmeye alınmayacağı kabul edilmektedir (Bahri Öztürk, Uygulamalı Ceza Muhakemesi Hukuku, İzmir; Dokuz Eylül Üniversitesi Yayını, 3. b., 1994, s. 395)... Buna aksi bir görüşü savunmak, özel kişilere bireylerin temel hak ve özgürlüklerini ihlal etme imkanı verir ki, bu bir hukuk devletinde kabul edilemez. Daha da önemlisi, bu tür delillerin hükme esas alınması 


\section{Dr. Bahattin ARAS}

Hukuka aykırı bir şekilde elde edilen delillere dayanılarak hukuka uygun bir idari işlem tesis etmek mümkün olmadığından bu tip deliller dayanak yapılarak verilen disiplin cezalarının "sebep unsuru" sakat niteliktedir. Disiplin işleminin sebep unsuru sakat olduğundan disiplin cezası verme işlemi hukuka aykırı hale gelmiş olacaktır. ${ }^{[27]}$

\section{2-) Hukuka Aykırı Delilleri Kullanma Yasağının Mutlak Bir Yasak Oluşu}

Burada unutulmaması gereken bir diğer husus da hukuka aykırı elde edilmiş delillerin kullanılmaması ilkesinin herhangi bir istisnasının bulunmamasıdır. Diğer bir ifade ile hukuka aykırı elde edilmiş delillerin kullanılmaması yasağı mutlak bir yasaktır. Dolayısıyla idarenin bu tip delilleri "kamu yararı, kurum düzeni veya kamu menfaati" gibi kavramları gerekçe göstererek disiplin soruşturmasında kullanması mümkün değildir. Zaten idare hukukunun temelinde var olan eşitsizlik ve idarenin disiplin sürecinde sahip olduğu pek çok üstün yetki ve ayrıcalıklar dikkate alındığında hukuka aykırı elde edilmiş delillerin disiplin cezası verilmesi için yeterli kabul edilmesi, teknolojinin çok geliştiği ve çoğu kişinin bu teknolojiye rahatlıkla ulaşabildiği şu dönemde bireylerin temel hak ve hürriyetleri için ciddi bir tehlikedir. Dolayısıyla somut olayın özellikleri, kamu yararının gerektirmesi gibi soyut ve içeriği kötüye kullanılabilecek, keyfi yorumlanabilecek gerekçelerle hukuka aykırı elde edilmiş delillerin disiplin hukukunda kullanılmasına istisna tanınması mümkün değildir. ${ }^{[28]}$

Özellikle teknolojik gelişmelere paralel olarak fiziki deliller kadar uyuşmazlıkların çözümünde ve suçların ortaya çıarılmasında önem arz etmeye başlayan elektronik veri ve kayıtlar bakımından hukuka uygun yöntemlerle elde edilmiş olma önem arz etmektedir. Elektronik verilerin elde edilmesi aşamasında hukuka aykırılık durumunun varlığı veya elektronik verilerin bütünlüğünün bozulması hallerinde bu veri ve kayıtlar belirti delili olarak dahi kullanılmaz. ${ }^{[29]}$

son zamanlarda toplumumuzda örnekleri görülen mafya oluşumlarını teşvik eder. (AYM, 1992/2 E., 2001/2 K., 22.06.2001 T.)

[27] GÜNEŞ, s.109

[28] GÜNEŞ, s.112

[29] KUNTER/YENISEY/NUHOĞLU, s. 1109; BAŞLAR, Yusuf. "Elektronik Delil Ve Ceza Yargılamasında Kabul Edilebilirliğine İlişkin Bir Inceleme” Legal Hukuk Dergisi”, Y. 2018, S.184, C.16, s.1677 
Kaldı ki, Anayasası'nın 36. maddesi gereğince herkes meşru vasıta ve yollardan faydalanmak suretiyle davacı veya davalı olarak iddia ve savunma ile adil yargılanma hakkına sahiptir. Bu hükümde geçen "meşru vasıta ve yollardan faydalanmak" ifadesi hak arama özgürlügünün, yani davacı veya davalı olarak iddia ve savunmada bulunma hakkının ancak hukuka uygun araç ve yöntemlerle kullanılabileceğini açıkça ortaya koymaktadır. Hakkında uygulanan disiplin cezasının iptalini isteyen davacı karşısında yer alan ve idari işlemi tesis eden idarenin de hukuka aykırı bir delile dayanması meşru bir savunma aracı olarak kabul edilemez. Maddi gerçeğin ortaya çıkarılması ancak hukuka uygun yöntemlerle elde edilmiş delillerle mümkündür. Maddi gerçeğin ortaya çıkarılması gerekçesiyle de olsa hukuka aykırı delillere dayanılamaz. Burada Anayasa'nın 38/6. maddesinden ve evrensel hukuk ilkelerinden kaynağını alan mutlak bir yasak vardır.

\section{B-) HUKUKA AYKIRI DELILLERIN DISIPLLIN SORUŞTURMALA- RINDA KULLANILAMAMASININ TEMEL GEREKÇELERI}

Anayasa'nın 2. maddesinde ifadesini bulan hukuk devletinde devletin görev, yetki ve sorumluluk alanlarının sınırları pozitif hukuk kuralları ve evrensel hukuk ilkeleri çerçevesinde belirlenmiştir. Devletin sahip olduğu kamu kudretinin sınırlarından biri de bireylerin hak ve hürriyetlerinin korunmasıdır. Diğer bir ifade ile kamu gücü karşısında kişinin hak ve özgürlüklerini korumak devletin yükümlülüğü altındadır. ${ }^{[30]}$

Hukuk devleti ilkesinin bir gereği olarak yargılama esnasında devletin delil elde etme ve hukuka aykırı delilleri değerlendirmesi konusunda konulmuş sınırlar bulunmaktadır. İlkenin bir gereği olarak devletin kendisi hukuka aykırı delil elde etmesi söz konusu olmadığı gibi herhangi bir şekilde elde edilmiş hukuka aykırı delilleri meşrulaştırma veya yargısal sürece dahil etmesi de mümkün değildir. Hukuk devleti ilkesinin delillerin hukukiliğine ilişkin çizmiş olduğu bu sınır ceza, hukuk ya da idari yargılama ve disiplin soruşturmalarının tamamı için geçerlidir. Dolayısıyla disiplin soruşturması sırasında da idare, gerçeği ortaya çıkarmak için kendisi hukuka aykırı delil elde etmeyecek ve hukuka aykırı yollarla elde edilen delilleri de kararına esas alamayacaktır. ${ }^{[31]}$

Disiplin soruşturmalarında hukuka aykırı yöntemlerle elde edilen delillerin karara esas alınması, hukuk devleti ilkesinin terki ve polis devleti

[30] GÜNEŞ, s. 103

[31] GÜNEŞ, s.104 


\section{Dr. Bahattin ARAS}

olma anlamına gelecektir. Zira polis devletinde devletin bireyin hak ve özgürlüklerini korumak amacıyla belirlenen bir sınırı bulunmamaktadır. Bu düzende "devlet" ya da "kamunun" menfaati ve refahı gerekçe gösterilerek her türlü önlem ve işlemin gerçekleştirildiği ve bireyin temel hak ve özgürlüklerine sınırsızca müdahale edilebildiği bir sistem vardır. Dolayısıyla hukuk devleti ilkesine aykırı olarak, disiplin hukukunda her türlü delilin kabul edilmesi, kişilerin hak ve hürriyetlerinin bertaraf edilmesinin yanı sıra idarenin keyfi ve hukuksuz davranışlarının da meşrulaştırılması demektir. ${ }^{[32]}$

Diğer taraftan disiplin cezalarını sadece meslek hayatına ilişkin yaptırımlar olarak değerlendirerek hafife almak ya da kurum düzenini sağlamak gerekçesiyle hukuka aykırı delillerle disiplin işlemi tesis etmek devlete duyulan saygınlığı ve güveni zedeleyecektir. Diğer bir ifade ile disiplin hukukunda hukuka aykırı elde edilmiş delilleri meşru ve kullanılabilir görmek bireylerin hukuki güvenliğine ve devletle olan güven ilişkisine zarar verecektir. $^{[33]}$

\section{C-) DISIPLIN SORUŞTURMASINDA HUKUKA AYKIRI DELIL DURUMLARI}

\section{1-) Aydınlatma veya Bilgi Verme Yükümlülüklerinin Yerine Getirilmemesi}

Disiplin soruşturmalarında gerek disiplin sürecine tabi olan kişinin ve gerekse soruşturma kapsamında dinlenen tanıkların ve diğer kişilerin soruşturma kapsamında beyanları alınmadan önce kanunlarda belirtilen esaslar çerçevesinde aydınlatılmaları gerekmektedir. Söz konusu aydınlatma veya bilgi verme yükümlülüklerinin yerine getirilmemesi veya usulüne uygun yapılmaması halinde alınan ifadelerin ve savunmaların sıhhatine gölge düşeceğinden bu şekilde düzenlenen savunma ve ifade tutanakları, hukuka aykırı delil kapsamında değerlendirilecektir. Bu şekilde düzenlenen tutanaklara dayanarak disiplin soruşturması yürütülmesi ve sonucunda ceza tesis edilmesi halinde, soruşturmanın ve tesis edilen cezanın hukuka aykııı olacağı da açıktır. Bu kapsamda soruşturma altındaki kişiye ithamın, ithama dayanak bilgi, belge ve delillerin, susma hakkının ve avukatla temsil hakkının bildirilmemesi, ifadesine başvurulan tanıklara

[32] ATAY, Ender Ethem, İdare Hukuku, Ankara 2016, s.106; GÜNEŞ, s.104

[33] GÜNEŞ, s.104; AKYILDIZ, s.239 
tanıklıktan çekinme hakkının hatıllatılmaması, ifade ve sorgu işlemlerinin kaydında teknik imkanlardan yararlanılmasında rızanın alınmaması gibi hallerin varlığı halinde elde edilen bu ifadeler hukuka aykırı delil durumuna gelecektir. ${ }^{[34]} \mathrm{Bu}$ belirtilen hususlar disiplin soruşturması bakımından da aynen geçerlidir.

\section{2-) Beyanların Yasak Sorgu-İfade Yöntemleri Kullanılarak Elde Edilmesi}

5271 sayılı Ceza Muhakemesi Kanunu'nun ifade alma ve sorguda yasaklanan usulleri düzenleyen 148. maddesindeki düzenleme uyarınca, kişinin savunması özgür iradesine dayanmalıdır. Kişinin özgür iradesini engelleyici nitelikte kötü davranma, işkence, ilâç verme, yorma, aldatma, cebir veya tehditte bulunma, bazı araçları kullanma gibi bedensel veya ruhsal müdahaleler yapılarak ya da Kanun'a aykırı bir yarar vaat edilerek ifade alınamaz. Maddedeki bu açık düzenlemeye aykırı olarak alınan ifadeler rıza ile verilmiş olsa da delil olarak değerlendirilmeyeceği maddenin 3. fikrasında hüküm altına alınmıştır.

Diğer taraftan Anayasa Mahkemesi 1999/2 Esas, 2001/2 Karar ve 22.6.2001 tarihli kararında “...Türk hukukunda "bukuka aykırlllk"tan ne kastedildiği ise gerek hukuk uygulamasinda gerekse doktrinde üzerinde tartı̧̧ma olmayan bir konudur. Türk hukuk sisteminde hukuka aykirllik, gerek yazil pozitif hukuk metinlerine gerekse hukukun evrensel uygulamaya kavusmus ilkelerine aykırllı anlamına gelir. Hukuka aykırllık en bașta milli bukuk sistemimiz içinde yürürlükteki tüm bukuk kurallarnna aykırılık anlamına gelir. Bu çerçeve içinde, anayasaya, usulüne uygun olarak kabul edilmiş uluslararası sözleşmelere, kanunlara, kanun bükmünde kararnamelere, tüzüklere, yönetmeliklere, içtihadı birleştirme kararlarına ve teamül hukukuna aykırı uygulamaların tümü hukuka aykırılık kavramı içinde yer alır. Bunun dışında, bukuk sistemimiz, hukukun genel ilkeleri adı verilen ve uygar dünyanın tüm medeni ülkelerinde uygulanan kurallar da bukuk kuralı olarak kabul etmektedir. Hukukun genel ilkelerinin neler olduğu konusunda bir belirsizlik olsa da, hukukun genel ilkelerinin hukuki bağlayıcilı̆ğ bulunduğu gerek uygulamada gerekse doktrinde tartışmasız olarak kabul edilmektedir. Anayasa Mahkememiz de birçok kararında, hukukun genel ilkelerinin varliğın kabul etmenin hukuk devletinin gereklerinden biri olduğunu ve bu ilkelerin yasakoyucu tarafindan dahi yok edilemeyeceğini hükme bağlamıştır (örneğin bkz. E. 1985/31. K. 1986/1, KT. 17.3.1986, Anayasa Mahkemesi Kararlar Dergisi,

[34] Fİ̧ ÜSTÜN, s.22-24 


\section{Dr. Bahattin ARAS}

S. 22. s. 115). Anayasa Mahkemesi 'nin bu görüşleri çerçevesinde bukukun genel ilkeleri, yasalardan, hatta Anayasanın değişstirilebilir hükümlerinden de üstün bir konuma getirilmiştir. Gerçekten de, bir anayasa hükmünü ve yasayn değisstirme gücüne sahip yasakoyucu hukukun genel ilkelerini yok etmeye yönelik bir yasama tasarrufunda bulunamaz. Özet olarak, Türk hukuk sisteminde "bukuka aykir şekilde" elde edilen deliller hiçbir şekilde kullanılamaz. Hukuka aykırllktan kasıt ise tüm pozitif hukuk kurallart ile birlikte hukukun kabul edilmiş evrensel ilkelerine aykirllıktır..." demek suretiyle Anayasa'ya ve hukukun genel ilkelerine aykırı bir şekilde elde edilen bulguların hukuka aykırı delil olduklarını ve kullanılamayacaklarını açıkça vurgulamıştır.

Hukuk devleti ilkesi ve adil yargılanma hakkı ile ceza hukuku ilkelerinin disiplin hukukunda da uygulanması gerektiğine dair yargı kararları çerçevesinde CMK'nın 148. maddesinde belirlenen esaslar, disiplin soruşturmaları bakımından da uyulması gereken temel esaslardır. Bu kapsamda disiplin soruşturmalarında, soruşturulan kamu görevlisinin veya ifade veren tanıkların, ifadelerinin alınması sırasında, soruşturmayı yürüten müfettiş veya muhakkik ya da disiplin konusunda karar verecek Kurul üyeleri ${ }^{[35]}$ tarafından aldatıcı beyanlarda bulunulması, kötü davranışlar sergilenmesi, cebir ve tehdit teşkil edecek eylemlerde bulunulması veya sözler sarf edilmesi, ifadesi alınanlara ilaç verilmesi veyahut hukuka aykırı vaatte bulunulması gibi hallerde alınan ifadeler hukuka aykırı delil niteliğinde olacaktır. İfade almada olduğu gibi soruşturmaya ilişkin delillerin toplanması sırasında da hukuka aykırı yöntem ve usullere başvurulmaması gerekir. $^{[36]}$

\section{3-) Adil Yargılanma Hakkı}

AİHS'nin 6 ve Anayasa'nın 36. maddelerinde düzenlenmiş olan adil yargılanma hakkı diğer temel hak ve özgürlüklerden farklı olarak, kişilere, hakkın kapsamına giren uyuşmazlıklara ilişkin yargılamalar yönünden

[35] Bu noktada OHAL döneminde ihraç edilen hakim ve savcılar hakkındaki soruşturmalara ilişkin "İtirafçılı̆gyla faydası olan FETÖ'cüleri yeniden hâkim ya da savcı yapabiliriz!” şeklinde açıklama yapan HSK Başkanvekili Mehmet Yılmaz'ın, daha sonra "Kurulumuz bu konuda kesin kararlıdır. Bu açıklamayı tamamen itirafçılığı teşvik amacıyla yaptım ve çok da başarılı oldum” açıklaması bu kapsamda hukuka aykırı yöntem niteliğindedir. Açıklama için bkz (HSYK Başkanvekili Yılmaz: İtirafçıllı̆ı teşvik etmek için o açıklamayı yaptım, https://tr.sputniknews.com/ turkiye/201612281026529306-hsyk-baskanvekili-itiraf-tesvik/, İET:22/07/2020.

[36] Fİ̧ ÜSTÜN, s.25 
"usuli güvenceler" sağlamaktadır. ${ }^{[37]}$ Devletin bütün kurum ve otoritelerinin bu güvencelere uygun hareket etmesi gerekmektedir. Bu bağlamda Anayasa’nın 11. maddesine göre, Anayasa hükümleri yasama, yürütme ve yargı organlarını, idare makamlarını ve diğer kuruluş ve kişileri bağlayan temel hukuk kuralları olduğundan, disiplin soruşturmaları dâhil tüm soruşturma ve kovuşturmalarda söz konusu ilkeye uygun hareket edilmesi ve bu soruşturmalar bakımından kişiye tanınan güvencelerin ihlal edilmemesi gerekmektedir. Dolayısıyla hukuka aykırı delillerin yargılamada kullanılmaması, adil yargılanma hakkı kapsamında kişiye tanınmış olan yargılama güvencelerinden biridir.

Disiplin cezası bir yargılama faaliyeti neticesinde verilmekten ziyade idari makamların gerçekleştirdiği idari tasarruflar neticesinde verilmektedir. Ancak idare, disiplin soruşturması ve disiplin cezası verme işlemi sırasında yarg1 benzeri bir faaliyet yürüttüğünden disiplin cezası verme işlemi sürecinde mümkün olduğu kadar yargılamaya hakim olan ilkelere uygun hareket etmelidir. Adil yargılanma hakkı da disiplin hukukunda kabul edilmesi gereken ilkelerden bir tanesi olduğundan hukuka aykırı elde edilmiş delillerin kabul edilmesi, adil yargılanma hakkına zarar vereceğinden disiplin soruşturması sürecinde kullanılması yasaktır. Ayrıca bu tip delillerin kullanıldığının idari işlemin iptali için açılan davada anlaşılması halinde idari yargı merciinin bu nedenle disiplin işleminin hukuka aykııı olarak verildiğine karar vermesi gerekir. ${ }^{[38]}$

\section{4-) Delillerin Elde Edilmesinde Hukuka Aykırı Yöntemlere Başvurulması}

Kamu görevlisi hakkında yürütülen disiplin soruşturması sürecinde kişinin iletişiminin izinsiz dinlenmesi, gizli ses ve görüntü alınması, bilgisayarların izinsiz incelenmesi, gizli soruşturmacı görevlendirilerek disiplin soruşturmasının yürütülmesi gibi hallerde elde edilen deliller, hukuka aykırı yöntemler kullanılması nedeniyle disiplin soruşturmasında kullanılamayacaktır.

\section{Avrupa İnsan Hakları Mahkemesi'nin Karabeyoğlu/Türkiye Kara-} $\mathbf{r i}^{[39]}$ bu konuda önemli tespit ve değerlendirmeler içermektedir. Başvurucu Cumhuriyet savcısı olarak görev yapmaktayken "Ergenekon" olarak bili-

[37] AİHM Anghel/İtalya Kararı, Başvur No: 5968/09, K.T:25/6/2013, Prg. 68

[38] GÜNDÜZ, s.108

[39] AİHM Karabeyoğlu/Türkiye Kararı, Başvuru No: 30083/10, K.T:07/06/2016 


\section{Dr. Bahattin ARAS}

nen yasadışı örgüt soruşturması kapsamında iletişiminin denetlenmesine karar verilmiştir. Yapılan soruşturma ve iletişimin denetlenmesinden elde edilen veriler sşığında Karabeyoğlu hakkında kovuşturmaya yer olmadığı kararı verilip iletişimin denetlenmesi kapsamında elde edilen verilerin imha edildiği kendisine bildirilmiştir. Ancak iletişimin denetlenmesi kapsamında elde edilen verilerin bir nüshası disiplin işlemleri bakımından değerlendirilmek üzere Adalet Bakanlı̆̆ı’ na gönderilmiştir. Bakanlık 12 Mart 2010 tarihli bir yazı ile başvuran hakkındaki disiplin soruşturmasının 5 Mart 2010 tarihinde ceza verilmesine yer olmadığı kararı ile sonuçlandığını ve telefon dinlemeleri süresince elde edilen kayıtların 11 Mart 2010 tarihinde imha edildiğini bildirmiştir.

Sözleşmenin 6. ve 8. maddelerini ileri süren başvuran, eşi ve çocukları ile birlikte kendisinin telefon görüşmelerinin izlenmesinin keyfi ve kanuna aykırı olduğunu; kendisine ait telefon görüşmelerinin gerek ceza soruşturması gerekse disiplin soruşturması çerçevesinde dinlenmesini keyfi ve yasadışı olduğunu iddia etmiş ve bu durumun şahsına ve unvanına zarar verdiğini eklemiştir.

Mahkeme, başvuranın dinlemeye alınmasına, tarafsız anlamda makul olarak değerlendirilen şüphelerin varlığı nedeniyle karar verilmiş olduğunu ve bu tedbirin uygulanmasının ilgili mevzuata uygun olduğunu; bu nedenle Mahkeme, başvuranın, aleyhine yürütülen ceza soruşturması kapsamında dava konusu yaptığı telefon dinlemeleri ile ilgili olarak Sözleşme'nin 8 . maddesinin ihlal edilmediğine karar vermiştir.

Ancak Mahkeme, başvuranın telefon hatlarının izlendiği sürede toplanan delillerin, başvuranın dava konusu yaptığı disiplin soruşturmasında kullanılmış olmasının birçok açıdan ulusal mevzuata aykırılık teşkil ettiğini belirtmiştir. Mahkemeye göre, her şeyden önce ne Anayasa’nın 22. maddesi ne de CMK'nın 135. maddesi dinleme tedbirlerinin uygulanabileceği durumlar arasında disiplin soruşturmalarına yer vermemektedir. Ayrıca, Telekomünikasyon yoluyla yapılan İletişimin Tespiti, Dinlenmesi, Sinyal Bilgilerinin Değerlendirilmesi ve Kayda Alınmasına Dair Usul ve Esaslar İle Telekomünikasyon İletişim Başkanlığının Kuruluş, Görev ve Yetkileri Hakkında Yönetmeliğin 4 ve 27. maddelerine göre, bu yönetmelik hükümlerine göre yürütülen faaliyetler çerçevesinde elde edilen kayitlar ve bilgiler, 5271 sayıl Kanun'un 135. maddesinde belirtilen amaçlar ve usul dışında kullanılamaz. Ayrıca, CMK'nın 137. maddesinin 3 ve 4. fikraları iletişimin denetlenmesi tedbiri yoluyla elde edilen verilerin, araştırmanın 
sonunda imha edilmesini öngörmektedir. Ancak somut olayda Mahkeme, 31 Aralık 2009 tarihli kovuşturmaya yer olmadığına ilişkin kararın ardından, ceza soruşturmasında yetkili Cumhuriyet savcısının dava konusu kayıtları 31 Aralık 2009 ve 5 Ocak 2010 tarihlerinde imha ettiğini ancak bunların bir kopyasının adalet müfettişlerinin elinde kaldığını ve adalet müfettişlerinin bu verileri başvuran hakkındaki disiplin soruşturması amacıyla kullandığını ve bu verilerin imhasını ancak disiplin soruşturmasının sonunda 11 Mart 2011 yılında gerçekleştirdiklerini gözlemlemiştir.

Mahkeme mevcut durumda toplanan bilgilerin amaç dışında kullanılması ve bu bilgilerin ceza soruşturmasının son bulmasının ardından gerekli olan 15 gün içinde imha edilmemesi olmak üzere mevzuata iki kez aykırılık teşkil ettiğini tespit etmiştir.

Bütün bu hususları göz önüne bulunduran Mahkeme, başvuran hakkında yürütülen disiplin soruşturması boyunca, ulusal makamlar tarafından mevzuat hükümlerinin hiçbirine saygı gösterilmediği ve başvuranın özel hayatına saygı hakkını ihlal eden bu müdahalenin, Sözleşme'nin 8. maddesinin 2. fikrası anlamında "kanunla öngörülmüş" olmadığı sonucuna varmıştır. Bundan dolayı, başvuranın telefonlarının dinlenmesi yoluyla elde edilen bilgilerin, başvuran hakkında yürütülen disiplin soruşturması kapsamında kullanılması nedeniyle Sözleşme’nin 8. maddesinin ihlal edilmiş olduğuna karar vermiştir.

Görüldüğü üzere Mahkeme, Karabeyoğlu’nun iletişiminin denetlenmesinden elde edilen veri ve kayıtların ayrıca disiplin soruşturmasında da aleyhine kullanıldığını, böylece özellikle hangi denetleme tedbirlerinin hangi şartlarda uygulanabileceğini belirten ve bu kapsamda disiplin soruşturmalarına değinilmeyen başta Anayasa’nın 22 ve CMK'nın 135. maddeleri olmak üzere iç hukukun ihlaline sebebiyet verildiğini gözlemlemektedir.

Mahkeme bu kararı ile Cumhuriyet savcısı başvurucunun, aleyhine yapılan ceza soruşturmasında tatbik edilen telefon dinleme yönteminden elde edilen hukuka uygun verilerin disiplin soruşturmasında kullanılmasını, bu tür bir kullanımın yasal dayanağı olmadığı gerekçesiyle Avrupa İnsan Hakları Sözleşmesi'nin 8. maddesi ile güvence altına alınan özel ve aile hayatına saygı hakkının ihlali saymıştır. Diğer bir ifade ile hukuka uygun verilerin disiplin soruşturmasında kullanılmasına imkan veren düzenleme olmaması nedeniyle bu verilerin disiplin soruşturması bakımından hukuka 


\section{Dr. Bahattin ARAS}

aykırı veri haline geldiğine hükmetmiştir. Zira, ceza yargılamasında hukuka uygun yol ve yöntemlerle elde edilen delillerin başka bir yargılamada kullanılabilmesi mümkündür. Ancak bu delillerin başka bir yargılamada kullanılabilmesi için, Anayasa'nın 13. maddesine uygun şekilde yasal bir dayanağın bulunması gerektiği tartı̧̧asızdır. Ceza yargılamasından elde edilen delillerin disiplin soruşturmasında kullanılabileceğine dair yasal bir dayanak bulunmadığından, AİHM ihlal kararı vermiştir.

Ayrıca unutulmamalıdır ki, imha edilen veya yasal olarak imha edilmesi gereken delillerin, yasal dayanak bulunsa bile başka bir soruşturmada kullanılması mümkün değildir. Çünkü bu deliller, imha kararıyla birlikte hukuka aykırı yol ve yöntemle elde edilmiş delil niteliği kazanmışlardır.

Anayasa Mahkemesi Eski Yargıtay üyesi hakkında Yüce Divan sıfatıyla baktığı davada ${ }^{[40]}$, hakim ve savcıların disiplin işlemlerinde görev alan müfettişler ve onların görev ve yetki alanlarına ilişkin önemli tespit ve değerlendirmeler yapmıştır. Anayasa Mahkemesi ilgili kararda işlem tarihi itibariyle Anayasa ve yasalarda adalet müfettişine koruma tedbirleri talep etme ve karar verme yetkisi bulunmamasına karşın bu yönde kararlar vermesi ve yetkisiz olarak re'sen verilen kararların sonradan hakim tarafindan onaylanmış olmasını, yapılan işlemleri hukuka uygun hâle getirmeyeceğini vurgulamıştır. Hukuka aykırı olarak uygulanan iletişimin denetlenmesi ve teknik araçlarla izleme tedbirleri sonucu elde edilen delillerin hukuka aykırı şekilde elde edilmeleri nedeniyle hükme esas alınmayacağına karar vermiştir. Mahkeme'ye göre Adalet Başmüfettişi'nin, yetkisi olmadan, çeşitli mahkemelerden aldığı kararlara dayanılarak iletişimin denetlenmesi ve teknik araçlarla izleme tedbirlerine başvurularak delil toplanması basit bir usul hatası olarak kabul edilemez. Çünkü yetkisiz olarak bir işlemin yapılması, onun geçerliliğine etki eder. Yetkisiz olarak başvurulan söz konusu tedbirler ile kişilerin özel hayatlarının gizliliğine ve haberleşme özgürlüklerine müdahale edilmiş olması da, hukuka aykırılı̆̆ın basit bir usul hatası olarak kabul edilmesine engeldir.

[40] AYM Hasan Erdoğan vd Karan, 2011/1 E., (Yüce Divan) 2012/1 K., 19.12.2012 T. 


\section{D-) ILETişiMIN DENETLENMESI KAPSAMINDA ELDE EDILEN VERILERIN DISIPLIN SORUŞTURMASINDA KULLANILMASI SORUNU}

\section{1-) Adli Amaçlı İletişimin Denetlenmesi Tedbirinden Elde Edilen Verilerin Durumu}

\section{a-) Tedbirin Kapsam ve Koşulları}

Yargı mercilerince yürütülecek adli soruşturmalar bakımından iletişimin denetlenmesine ilişkin usul ve esaslar 5271 sayılı Ceza Muhakemesi Kanunu'nun 135 ila 138. maddeleri arasında düzenlenmiştir. Adli bir soruşturma kapsamında haberleşme hürriyetinin kısıtlanması sonucunu doğuran iletişimin denetlenmesi tedbirine başvurulmasının gerekmesi halinde CMK'nın 135. maddesinde belirtildiği üzere suç işlendiğine ilişkin somut delillere dayanan kuvvetli şüphe sebeplerinin varlığı ve başka surette delil elde etme imkanının bulunmaması durumunda hakim kararıyla ya da gecikmesinde sakınca bulunan hallerde Cumhuriyet savcısının kararıyla kişi hakkında bu tedbire başvurulabilir. Görüldüğü üzere adli amaçlı bir iletişimin denetlenmesi kararı verilebilmesi için gerekli olan koşullar Kanun'da açıkça belirtilmiştir. ${ }^{[41]}$ Buna göre;

- Kişi hakkında atılı suça dair somut delillere dayanan kuvvetli şüphe sebeplerinin varlığı,

- Başka surette delil elde etme imkanının bulunmaması (Son çare prensibi),

- Yukarıdaki iki koşulun bulunması halinde hakim kararının ya da gecikmesinde sakınca bulunan hallerde Cumhuriyet savcısının kararının bulunması

şeklindeki bu üç temel, emredici, vazgeçilmez ve birlikte bulunması gereken şartların varlığı halinde bu tedbire başvurulabilir. Görüldüğü üzere, CMK'nın ilgili hükümleri bir bütün olarak değerlendirildiğinde doğrudan yürütülen bir disiplin soruşturması nedeniyle adli amaçlı iletişimin denetlenmesi tedbirine başvurulamaz. Buna rağmen mahkeme tarafından buna izin verilmesi halinde karar hukuka aykırı olacağı gibi elde edilen deliller

[41] ŞAHIN, Cihan, "Hâkim ve Cumburiyet Savcılar İle HSYK ve Yargıtay Üyelerinin İletişimlerinin Denetlenmesi”, TAAD, Y.3, Temmuz 2012, S.10, (İletişimin Denetlenmesi), s.586-587; KAYMAZ, Seydi, Ceza Muhakemesinde Telekomünikasyon Yoluyla Yapılan İletişimin Denetlenmesi, Ankara 2011, s.208-209 
de hukuka aykırı olacaktır. ${ }^{[42]}$

\section{b-) Tedbir Kapsamında Elde Edilen Verilerin Disiplin Soruş- turmasında Kullanılması}

Görüldüğü üzere CMK'nın 135. maddesinde son çare olarak başvurulması gereken ve sıkı koşullara bağlanan adli amaçlı iletişimin dinlenmesi tedbirinin uygulanmasıyla elde edilen bilgiler, hangi amaçla elde edilmişse, ancak o amaç için kullanılabilecektir. Disiplin soruşturmasında iletişimin denetlenmesi yoluna imkan veren yasal bir düzenlemenin de bulunmad1$\breve{g} 1$ hususu dikkate alındığında, ceza soruşturmasında elde edilen iletişimin denetlenmesi tedbirinden elde edilen verilerin disiplin soruşturmasında kullanılması, dolaylı yollardan iletişimin denetlenmesi anlamına gelecektir. $\mathrm{Bu}$ ise kanuna karşı hile olacağından hukuka aykırı yollarla delil elde etme anlamına gelecektir. ${ }^{[43]}$ Dolayısıyla, bunlar soruşturma konusu suçla ilgisi olmayan, ancak disiplin suçunu oluşturabilecek nitelikteki fiilleri işlediği tespit edilen kamu görevlisinin disiplin soruşturmasında kullanılamaz. Mesela örgüt üyeliği suçlamasından verilmiş bir dinleme kararında örgüt üyeliği suçu dışında ve aynı zamanda katalog suçlardan da olmayan bir suçun tespiti halinde bu suç yönünden nasıl bu kayıtlar delil olarak kullanılamıyorsa bu suç nedeniyle yürütülecek disiplin soruşturmasında da bu kayıtlar kullanılamaz. Bu türden kayıtlar, CMK'nın 135/8. maddesindeki kısıtlayıcı "katalog suçlarla sınırlı kullanma” prensibi gereğince sadece belli suçlar bakımından ceza yargılamasında delil olarak değerlendirilebilir.

Bu nedenle kanuni bir dayanak olmaksızın elde edilen söz konusu delillerin disiplin soruşturmasında kişi aleyhine kullanılması mümkün değildir. Anayasa'nın 13. maddesi uyarınca kişi temel hak ve hürriyetlerinin özlerine dokunulmaksızın yalnızca Anayasa'nın ilgili maddelerinde belirtilen sebeplere bağlı olarak ve ancak kanunla sınırlanabileceği belirtilmektedir. CMK'nın 135/8. maddesinin açık hükmü ve bu istisnai tedbirden elde edilen kayıtların disiplin soruşturmasında kullanılabileceğine ilişkin yasal düzenleme de bulunmaması nedeniyle bu kayıtların disiplin soruşturmasında kullanılması mümkün değildir. Bu istisnai tedbirin kamu yararı ve güvenliği gibi genel kavramlarla genelleştirilmesi insan hak ve hürriyetleri-

[42] BAŞ, Eylem, "Hâkimlerin ve Savcıların Disiplin Yönünden Soruşturulmaları ve İs̆ledikleri Suçlar Nedeniyle Yargılanmaları”, Ankara Barosu Dergisi, Y.2016, S.3, s.302

[43] DEMİR, Nazlı Hilal, Yasak Deliller ve İnsan Onuru, İstanbul Kültür Üniversitesi Sosyal Bilimler Enstitüsü Yayınlanmamış Yüksek Lisans Tezi, İstanbul 2012, s.89 
nin korunması bakımından büyük bir tehlike oluşturacağı açıktır. Delil yasaklarına ilişkin olarak "delil değerlendirme yasăğ" kapsamında bir durum söz konusu olduğundan hukuka uygun bir kararla elde edilmiş olsa bile bu kayıtların disiplin soruşturmasında kullanılması mümkün değildir ${ }^{[44]}$. Ancak adli amaçlı iletişimin denetlenmesi tedbirinden elde edilen kayıtlar kamu görevlisinin görev yaptığı idare bakımından bir ihbar niteliğinde değerlendirilebilir. Bu durumda ilgili idare, kamu görevlisi hakkında disiplin soruşturması açabilir fakat soruşturmada bu kayıtlara dayanmadan, toplayacağı başkaca delillere göre disiplin soruşturmasını neticelendirmelidir. ${ }^{[45]}$

Adli amaçlı yapılacak bu iletişimin denetlenmesi tedbirinin, ilgili adli kolluk mercileri tarafından bu maddelerde belirtilen esaslara göre yerine getirilmesi gerekir. Aksi takdirde yapılacak iletişimin denetlenmesi "hukuka aykırı” hale gelecektir. Bu aynı zamanda zarar doğrucu bir işlem olması nedeniyle tazminat davasına konu edilecektir. Nitekim Danıştay 10. Dairesi vermiş olduğu bir kararında ${ }^{[46]}$ "Anayasal güvence altında bulunan haberleşme özgürlüğ̈̈nün zedelenmesine neden olmak suretiyle, davacının resmi telefonunun davalı idarede çalışan görevlilerce hukuka aykırı bir şekilde dinlenmesini engelleyecek bir tedbirin alınmaması, idarenin ağır hizmet kusurunu oluşturur. Bu yüzden davacının uğradığı manevi zararın tazmin edilmesi gerekmektedir..." demek suretiyle bırakın hukuka aykırı dinlemeyi, kişinin hukuka aykırı dinlenmemesi için gerekli tedbirleri almadığı için idareyi tazminata mahkum etmiştir. Danıştay bir başka bir kararında ise, “... Anayasayla güvence altına alınmıs bulunan haberleşmenin gizliliği esasının göz ardi edilerek, hakim kararı ya da gecikmesinde sakınca bulunan hallerde yasayla yetkili kılınmış bir merciin emri olmaksızın, davacıya ait telefon konuşmalarının idare ajanları tarafindan dinlenmesinde, idarenin ăgır hizmet kusuru bulunduğu ve bunun sonucunda davacının uğradiğı manevi zararın ödenmesinin yerinde olduğu' demek suretiyle idare tarafından gerçekleştirilen usulsüz dinlemelerden dolayı idareyi tazminata mahkum etmiştir. ${ }^{[47]}$

Diğer taraftan Danıştay, bir kimse hakkında ceza soruşturması yapıldığı sırada, hakim kararına dayanılarak gerçekleştirilen iletişimin denetlen-

[44] ARSLAN, Çetin, "Ceza Muhakemesinde İletişimin Denetlenmesi Yoluyla Elde Edilen Delillerin Disiplin Hukukundaki Durumu Üzerine Bir Değerlendirme”, Fasikül Hukuk Dergisi Y.2010, C.2, S.3, s.37-40; CANOĞLU, s.261

[45] GÖKPINAR, s. 147; DEMİ, s.89

[46] Danıştay 10. D., 2000/2926 E., 2000/6227 K., 6.12.2000 T.

[47] Danıştay 10. D., 2000/3896 E., 2000/6228 K., 6.12.2000 T. 


\section{Dr. Bahattin ARAS}

mesi yoluyla elde edilen dinleme kayıtlarını, disiplin soruşturmasında delil olarak kabul etmekteydi. ${ }^{[48]}$ Yukarıda da izah ettiğimiz üzere Danıştay'ın bu kararı hem Anayasa’nın 36. hem de 38. maddesi kapsamında hukuka açıkça aykırıdır. Zira kişinin temel hak ve özgürlüklerine müdahale niteliğinde olan adli amaçlı iletişimin denetlenmesi tedbiriyle kişinin özel yaşamına ve haberleşme özgürlüğüne müdahale edildiğinden bu kayıtların amacı dışında disiplin soruşturmasında delil olarak kullanılması halinde, bu durum vicdani delil sisteminin hukuka uygunluk sinırına takılmaya ve mahkemede delil olarak kabul edilmemeye mahkumdur.

Ancak, Danıştay yakın dönemlerde kararlarını değiştirmiş, Anayasa'nın 38. maddesinde öngörülen hukuka aykırı elde edilen bulguların delil olarak kullanılmaması yönündeki ilkenin disiplin soruşturmalarında da uygulanması gerektiğine hükmetmiştir. ${ }^{[40]}$ Danıştay 5. Dairesi ${ }^{[50]}$ Anayasa Mahkemesi'nin 2014/100 Esas, 2015/6 Karar ve 14.1.2015 tarih sayili, ceza hukukunun temel ilkelerinin disiplin hukuku açısından da geçerli olduğunu kabul ettiği kararına atıfta bulunarak; disiplin cezası verilmesinde asıl delil olarak kullanılan telefon kayıtlarının Ceza Muhakemesi Kanunu'nun 135. maddesinde yer alan suçlar kapsamında bulunmayan bir fiile ilişkin olduğu ve bu fiile ilişkin ses kayıtlarının, tek başına delil olarak kullanılamayacağını ifade ettikten sonra, hukuka uygun olarak elde edilmiş başka delil ve belgeler olmaksızın sadece bu delillere dayanılarak disiplin cezası verilemeyeceğine hükmetmişsir.

\section{2-) Önleyici Amaçlı İletişimin Denetlenmesi Tedbirinden Elde Edilen Verilerin Durumu}

\section{a-) Tedbirin Kapsam ve Koşulları}

Kişinin adli amaçlı iletişimine müdahale haricinde ilgili kanunlarda belirtilen koşulların varlığı halinde istihbari amaçlı olarak da kişinin iletişimi denetlenebilir. İstihbari/önleme amaçlı yapılacak iletişimin denetlenmesi konusunda 2559 sayılı Polis Vazife ve Selahiyet Kanunu Ek 7. maddesiyle polise, 2803 sayılı Jandarma Teşkilat, Görev ve Yetkileri Kanunu Ek 5. maddesiyle jandarmaya, 2937 sayılı Devlet İstihbarat Hizmetleri ve Milli İstihbarat Teşkilatı Kanunu'nun 6/2. maddesiyle de Milli İstihbarat Teşki-

[48] Danıştay 12. D., 2008/4042 T., K: 2008/7250 K., 24.12.2008 T.

[49] Fİş ÜSTÜN, s. 17

[50] Danıştay 5. D., 2016/18730 E., 2017/21649 K., 25.10.2017 T. 
latına yetki verilmiştir.

Diğer taraftan MİT tarafından usulüne uygun olarak alınmış olan istihbari amaçlı iletişimin denetlenmesi tedbiri kapsamında elde edilen verilerden bir suçun işlendiğinin anlaşılması halinde ilgili kayıtların adli mercilere gönderilmesi gerekir. Ancak burada Kanun'un EK-1. maddesindeki kısıtlamaya uygun hareket edilmesi gerekir. Burada adli suç için gönderilen istihbari veriler doğrudan delil olmaktan ziyade suçun işlendiğine yönelik belirti niteliğinde olup sadece adli makamların soruşturmayı başlatmalarını sağlayacak niteliktedir. Adli merciler bu verileri kullanarak adli amaçlı iletişimin denetlenmesi tedbiri kararı alarak soruşturmaya devam edebilirler. Yoksa doğrudan bu verileri adli soruşturmada kullanmaları mümkün değildir. Bu bağlamda geçmişte Yargıtay Ceza Genel Kurulu da vermiş olduğu birçok kararında ${ }^{[51]}$ istihbari amaçlı yapılan iletişimin denetlenmesi sonucunda ulaşılan bulguların yasanın öngördüğü amaçlar dışında ve bu arada bir ceza soruşturması ve kovuşturmasında "delil" olarak kullanılmasının mümkün olmadığını belirtmiştir. Bu husus disiplin soruşturmaları bakımından da geçerlidir.

\section{b-) Tedbir Kapsamında Elde Edilen Verilerin Disiplin Soruş- turmasında Kullanılması}

Önleyici amaçlı iletişimin denetlenmesi tedbirine karar verildiğinde ortada henüz işlenmekte olan bir suç bulunmamaktadır. Burada delil elde etmek gibi bir amaç bulunmamaktadır. Aksine burada temel amaç bu yolla elde edilen veri ve kayıtlar vesilesiyle suçların işlenmesinin önüne geçmektir. Zaten PVSK'nın ek 7/6, JTGYK'nın ek 5/6, Mi̇T Kanunu 6/7. maddelerinde yer alan "bu madde hükümlerine göre yürütülen faaliyetler çerçevesinde elde edilen kayıtlar birinci fikrada belirtilen amaçlar dışında kullanılamaz "ifadesi bu amacı ortaya koymaktadır. Ayrıca yasa koyucu bu düzenlemede, "delil" ibaresi yerine, "elde edilen kayıtlar" ibaresine yer vererek önleyici amaçla uygulanan tedbir ile elde edilen bilgilere delil gücü tanımak istememiş olduğunu ortaya koymaktadır. ${ }^{[52]}$ Dolayısıyla önleyici amaçlı iletişimin denetlenmesi kapsamında elde edilen bu tür delillerin duruşmada metne dönüştürülmesi ya da dinlemeyi yapan görevlinin tanık

[51] Yargitay CGK., 2012/1283 E., 2014/430 K., 21.10.2014 T.

[52] TURHAN, Faruk/AKSU, Muharrem, "İnsan Haklarının Korunması Açısından Önleyici Amaçlı İletişimin Denetlenmesi Tedbiri”, Uluslararası Davras Kongresi, Küresel Dialog, 24-27 Eylül 2009, ekitap, Isparta, s. 2212 


\section{Dr. Bahattin ARAS}

olarak dinlenmesi veyahut bu tür verilerin rapor haline getirilmesi suretiyle ceza yargılamasında ya da disiplin soruşturmalarında kullanılabilmesi mümkün değildir. ${ }^{[53]}$ Dolayısıyla, disiplin hukukunda iletişimin denetlenmesine karar verilmesi konusunda mevzuatta açıkça öngörülen yasal bir sinırlandirma vardır.

Aynı şekilde PVSK ek 7/6, JTGYK ek 5/6, MİTK 6/7. maddelerinde geçen düzenlemeler dolayısıyla önleme amaçlı iletişimin denetlenmesi yoluyla elde edilen kayıtların bir ceza soruşturması/kovuşturması aşamasında ya da disiplin soruşturması kapsamında kullanılması mümkün değildir. ${ }^{[54]}$ Bu kapsamda güncel adli soruşturmalar bağlamında tartışma konusu olan husus MİT tarafından bir kısım iletişimin denetlenmesi kapsamındaki verilerin 2937 sayılı Kanun'un MİT’in görevlerini düzenleyen 4. maddesi kapsamında ceza ve disiplin soruşturma dosyalarına gönderilmesi ve daha sonra bu verilerin ceza ve disiplin soruşturmasında ilgililer aleyhinde delil olarak kullanılmasıdır.

MİT tarafından yapılacak istihbari/önleme amaçlı iletişimin denetlenmesine ilişkin hususlar 2937 sayılı Kanunun 6. maddesinin ikinci fikrasında yer almaktadır. Burada iletişimin denetlenmesi kapsamındaki verilerin toplanması ve kayda alınmasına ilişkin özel düzenlemeye yer verilmiştir. Dolayısıyla Kanun'un 6/2. maddede elde edilme usulü düzenlenmiş iletişimin denetlenmesi kapsamındaki verilerin, MİT'in genel görevlerini düzenleyen Kanun'un 4. maddesi esas alınarak doğrudan elde edilmesi ve diğer kamu kuruluşlarıyla paylaşılması mümkün değildir. Daha önce de belirtildiği üzere ancak Kanun'un 6/2. maddesinde belirlenmiş olan usul ve esaslar çerçevesinde elde edilmiş olan haberleşme verileri EK-1. maddedeki suçlar bakımından paylaşılabilir.

Kanun'un bu açık hükümlerine rağmen MİT tarafindan önleyici amaç$l_{1}$ iletişimin denetlenmesi kararı alınmadan ve harici yöntemler kullanılarak elde edilen ByLock mesajlaşma programına ilişkin içerik ve verilerin ceza ve disiplin dosyalarında kullanıldığı Yargıtay ve Danıştay kararlarında görülmektedir. Ancak;

[53] İPEK, s.248; TAŞKIN, Mustafa, Adli ve İstihbari Amaçlı İletişimin Denetlenmesi, Ankara 2008, s.225

[54] TAŞTAN, Mehmet, "Telekomünikasyon Yoluyla Gerçekleştirilen İletişimin Önleme Amaçlı Olarak Denetlenmesinin Amaç Kapsam ve Sinırları ”, Terazi Aylık Hukuk Dergisi, Y. 4, Ocak 2009, S.29, s.101 
- Söz konusu verilerin 2937 sayılı Kanun'un 6/2. maddesi kapsamında alınmış bir istihbari amaçlı iletişimin denetlenmesi kararına dayanmamış olması,

- Bu verilere ilişkin mahkeme kararı veya onayı bulunmaması nedeniyle bu verilerin hukuka aykırı delil niteliğinde olması,

- İstihbari amaçlı iletişimin denetlenmesi tedbiri kapsamında elde edilen veri ve kayıtların 2937 sayılı Kanun'un 6/6. maddesinde belirtilen temel amaç olan "istihbari amaç" dışında kullanılamaması,

- İstihbari amaçlı iletişimin denetlenmesi tedbiri kapsamında elde edilen veri ve kayıtlar ile yapilan analizlerin 2937 sayılı Kanun'un EK-1. maddesindeki düzenleme uyarınca ancak Türk Ceza Kanunu'nun 2. Kitap 4. Kısım 7. Bölümde yer alan suçlar bakımından adli mercilerle paylaşılabilmesi karşısında elde edilen bu veri ve kayıtların disiplin soruşturmalarında kullanılması hukuka aykıııdır.

İletişimin denetlenmesi tedbirinin ihlal alanı haberleşme hürriyeti ve özel hayatın gizliliği olduğundan Anayasa ve yasaların bu temel hak ve hürriyetlerin denetlenmesine imkan veren "istisnai" hükümlerinin "yorum" yöntemiyle genişletilmesi mümkün değildir. Terör örgütlerinden kaynaklı tehditlerin zamanla şekil ve yöntem değişikliğine uğramasından dolayı bu tehditleri bertaraf edici tedbirlerin alınması zorunlu olsa da, demokratik hukuk devletinde kişi hak ve özgürlüklerinin özünü zedeleyen veya aşırı şekilde sınırlayan müdahalelere karşı bunların yasal düzenlemelerle korunması da hukuk devleti ilkesinin en tabii ve zaruri sonucudur. Bu aynı zamanda her idari işlem ve eylem de olduğu gibi yargısal işlem ve kararlarda da "keyfiliğ̈in" engellenmesi için bir gerekliliktir.

\section{3-) Tesadüfi Delillerin Durumu}

\section{a-) Genel Olarak Tesadüfi Deliller}

Tesadüfen elde edilen deliller, hukuka uygun olarak yürütülen bir gizli bilgi toplama faaliyeti sırasında elde edilen, ancak soruşturma konusu olan suçla bir ilgisi olmayıp, bir başka suçun ispatına yarayan delillerdir. Diğger bir ifadeyle, tesadüfen elde edilen deliller, yapılan araştırma ile ilgisi bulunmayan ve soruşturma yapılırken ele geçirilen, bir başka suçun işlendiğini gösteren delillerdir. ${ }^{[5]}$ CMK'nın "Tesadüfen elde edilen deliller" başlığını

[55] DEMİR, s.105; ÖZTUNÇ, Özgün, "Ceza Muhakemesi Açısından Yasak Deliller ve Disiplin Soruşturması Açısından Yasak Deliller ile Tesadüfen Elde Edilen Delille- 


\section{Dr. Bahattin ARAS}

taşıyan 138. maddesindeki düzenleme uyarınca sadece arama ve elkoyma ile iletişimin denetlenmesi tedbirleriyle sınırlı olmak üzere tesadüfi deliller uygulama alanı bulacaktır. Bu konudaki temel kural, hukuka uygun bir arama, el koyma ve iletişimin denetlenmesi sırasında elde edilen ve diğer bir suçun ispatına yarayan delilin hukuka uygun olduğu ve hükme esas alınabileceğidir (CMK m.138/1). Ancak iletişimin denetlenmesinde tesadüfen elde edilen delilin soruşturmada kullanılabilmesi için delilin katalog suçlardan biriyle ilgili olması gerekir.

Ceza yargılamasına ilişkin yasal düzenlemeler uyarınca kural olarak şüphelinin iletişiminin denetlenmesinin amacı, işlenmiş olan katalog suçlardan birine ilişkin delil elde etmek olduğundan bu nitelikte bir bilgi veya bulgu elde edildiğinde bunların delil olarak kullanılacağı açıktır. Aynı şekilde bu dinleme tedbirinden şüphelinin, soruşturma konusu suçtan başka, ancak bir başka katalog suç işlediğine dair bilgiler elde edilirse bu bilgiler de delil olarak kullanılabilecektir. Örnek verilecek olursa, uyuşturucu ticareti suçu ile ilgili şüpheli hakkında dinleme kararı alınmış ve yapılan dinleme sırasında şüphelinin bir adam öldürdügüne ilişkin bilgi ve bulgu elde edilirse, Cumhuriyet savcısı eldeki bilgileri dikkate alarak adam öldürme suçundan da soruşturma açabilecektir. Ancak tesadüfen elde edilen deliller kapsamında şüpheli veya sanığın başka bir katalog suçu işlediğine dair bilgiler elde edilirse, bu katalog suçla ilgili doğrudan iletişimin denetlenmesine devam edilemez. Bu suç bakımından koşulların varlığı değerlendirilmeli ve ayrı ve yeni bir karar verilmesi halinde tesadüfen tespit edilen suçla ilgili iletişimin denetlenmesi gerçekleştirilebilir. Eğer, CMK 138/2. maddesinde gösterilen usule uygun hareket edilmemiş, tesadüfen elde edilen delil ile soruşturma dosyası düzenlenmiş ve yeni ortaya çıktı̆̆ ileri sürülen suçla ilgili olarak, CMK 135. maddesine uygun olarak iletişimin denetlenmesi kararı alınmamışsa, toplanan deliller hukuka aykırı olarak nitelendirilecek ve kovuşturmada değerlendirilmeyecektir. ${ }^{[5]}$

Tesadüfen elde edilen delillerin katalog suçlar haricinde bir suça ilişkin olması durumunda bu kayıtlar soruşturma başlatılması konusunda ihbar olarak değerlendirilebilir. ${ }^{[57]}$ Ancak bu kayıtların kişi hakkındaki nihai ka-

rin Değerlendirilmesi”, s.3, http://www.ozgunlaw.com/Uploads/image/files/Makale22072011 DrOzgunOztunc.pdf, İET:29.12.2019

[56] ÖZTUNÇ, s.3; DEMİR, s. 106

[57] ŞEN, Ersan, "İletişimin Dinlenmesi Tedbiri”, Ceza Hukuku Dergisi, Ağustos 2007, (2007), s. 128 
rarda delil olarak değerlendirilmesi mümkün değildir. Bununla birlikte öğretide, katalog suçlar dışında kalan suçlarla ilgili olarak tesadüfen elde edilen bilgilerle soruşturma dahi başlatılamayacağı ileri sürülmektedir. ${ }^{[58]}$

Diğer taraftan gerek Anayasa'da ve gerekse Avrupa İnsan Hakları Sözleşmesi'nde açıkça kanun ile saptanmış sınırlar kapsamında haberleşmenin gizliliğine müdahale edilebileceği ve bu müdahale kapsamında elde edilen delillerin değerlendirilmesinin de iç hukukun açıç̧a belirttiği suçlar için mümkün olduğu unutulmamalıdır. Aksinin kabulü halinde, Avrupa İnsan Hakları Sözleşmesi'nin adil yargılanma ilkesinin düzenlendiği 6 . maddesi ile özel hayatın gizliliği ilkesinin düzenlendiği 8. madde hükümlerine aykırı uygulamalar ortaya çıkacaktır.

\section{b-) Disiplin Soruşturmasında Tesadüfi Delillerin Durumu}

CMK'nın 138/2. maddesindeki düzenleme uyarınca iletişimin denetlenmesi sırasında, denetime konu olan eylem ve fail dışındaki üçüncü bir şahıs ya da fiille alakalı olarak elde edilen delillerin kullanılabilmesi, bu delilin CMK 135/6. maddesinde sayılan katalog suçlardan birisi ile ilgili olmasına bağlıdır. Eğer elde edilen tesadüf nitelikteki bu deliller, katalog suçlardan biri ile ilgili değilse delil değerine sahip değildir. Bu husus, disiplin hukuku açısından da geçerlidir. Zira Anayasa'nın 38. maddesinin bir gereği olarak hukuka uygun bir dinleme kararından kaynaklı olsa da bu kayıtlar delil yasaklarına ilişkin "değerlendirme yasağı" kapsamında disiplin soruşturmasında değerlendirilemez. Kaldı ki CMK'nın 135/6. maddesi uyarınca katalog suç olmayan bir suçun soruşturulmasında kullanılmayan bu verilerin disiplin soruşturmasında kullanılması söz konusu olamaz.

Yargıtay bir kısım kararlarında, tesadüfen elde edilen delillerin, ceza yargılamasında kullanılamayacağına yönünde karar vermesine karşın bu delillerin, disiplin soruşturması yönünden kullanılabileceğine karar vermiştir. Şöyle ki; Yargıtay bir kararında ${ }^{[59]}$; “... hukuka aykırı elde edilmis deliller nedeniyle hakkında beraat kararı verilen Cumburiyet Savcısinin ...fiillerinden dolay 2802 sayzl Kanun'un 87. maddesi gereğince disiplin suçu yönüyle değerlendirilmesi Hakimler ve Savcllar Yüksek Kurulunun takdirlerine sunulmasi gerekli görülmüştür..." demek suretiyle bu tesadüfi delillerin disiplin yönünden değerlendirilebileceğine karar vermiştir. Ceza Genel

[58] YENİSEY, Feridun/ ALTUNÇ, Sinan, "İletişimin Dinlenmesi Hakkında", http:// www.turkhukuksitesi.com/showthread.php?t=15125, İET: 01/03/2020

[59] Yargitay 5. CD., 2006/6 E., 2006/4 K., 14.06.2006 T. 


\section{Dr. Bahattin ARAS}

Kurulu da dairenin bu kararını bu yönüyle uygun bulmuştur. ${ }^{[60]}$ Yargıtay Birinci Başkanlık Kurulu tarafından verilen bir kararda ise; sanıkların, bir kısım Yargıtay üyeleri ile yakın ilişki kurdukları, onların ad ve nüfuzlarını kullanarak ilgilendikleri dava ve işlere bakan hakimler üzerinde etkili olmaya çalıştıkları iddia edilmiş ve telefonları dinlenen sanıklar ile haklarında dinleme kararı bulunmayan üçüncü kişi konumunda olan Yargıtay üyelerinin hukuki durumları tartışılarak, soruşturma yapılan kişiler yönünden yöntemine uygun dinleme kararı alınmadığından, bu yöntemle elde edilen kanıtların ceza yargilamasında delil olarak kullanılmayacağına karar verilmesine karşın iki Yargıtay üyesi hakkında yakınlarını kollama niyetiyle gerçekleştirdiği bazı telefon görüşmeleri sebebiyle (tesadüfen elde edilen tespitler), disiplin kovuşturması yapılmasına karar verilmiştir. ${ }^{[61]}$

Yargitay'in tesadüfi delillerin disiplin soruşturması yönünden kullanılabileceğine ilişkin verdiği bu kararlar, hukuka uygun değildir. Zira, Anayasa’nın 38. maddesi ve maddenin Anayasa Mahkemesi tarafından geliştirilen uygulaması bakımından yürütülen soruşturmalarda, hukuka aykırı şekilde elde edilen delillerin, disiplin soruşturmasında kullanılması mümkün değildir. Bu bağlamda CMK'nın 138/2. maddesi kapsamında katalog suçlar dışında tesadüfi delillerin kullanım yasağı dikkate alındığında bu delillerin disiplin soruşturması bakımdan "delil değerlendirme yasağı” kapsamında kaldığı ve hukuka aykırı hale geldiği açıktır. Buna rağmen bu delillerin kullanılması adil yargılanma hakkının ihlali niteliğinde olacaktır.

\section{E-) ULUSAL VE ULUSLARARASI YÜKSEK MAHKEMELERIN BA- KIŞ AÇISI}

\section{1-) Avrupa İnsan Hakları Mahkemesi'nin Değerlendirmesi}

Avrupa İnsan Hakları Sözleşmesi'nin adil yargılanma hakkını düzenleyen 6. maddesinde ve diğer maddelerinde hukuka aykırı delillere ilişkin bir hüküm yer almamaktadır. AİHM, hukuka aykırı delillerin yargılama sırasında dikkate alınıp alınmamasını daha çok bir iç hukuk meselesi olarak değerlendirmekte ve yargılamayı bir bütün olarak ele almaktadır. Bu bağlamda mahkûmiyet kararının bu hukuka aykırı elde edilen delile dayanıp dayanmadığına göre yargılamanın adil olup olmadığına hükmetmektedir.

[60] Yargitay CGK., 2007/5 MD-23 E., 2007/167K., 03.07.2007 T.

[61] Yargıtay Birinci Başkanlık Kurulunun 29.6.2004 tarihli ve 2004/96 sayılı kararı (www.kazanci.com) 
Ancak Mahkeme, işkence, insanlık dışı ve onur kırıcı muamele yasağı gibi bazı Sözleşme maddelerinin ihlal edilerek toplanan delillere dayanılması halinde, mahkumiyet kararının bu delillere dayanıp dayanmadığına bakmaksızın adil yargılanma hakkının ihlaline hükmetmektedir. ${ }^{[62]}$ Aynı şekilde Mahkeme Karabeyoğlu/Türkiye Kararında ${ }^{[63]}$ olduğu gibi doğrudan hukuka aykırı delil tanımlamasına girmeden delillerin toplanmasına ve soruşturmalarda kullanılmasına ilişkin iç hukukta yer alan düzenlemeler üzerinden bu konuda tespit ve değerlendirmelerde bulunmaktadır. Mahkeme Karabeyoğlu/Türkiye Kararında delillerin değerlendirme yasağ 1 kapsamında mevcut durumda toplanan bilgilerin amaç dışında disiplin soruşturmasında kullanılması ve bu bilgilerin ceza soruşturmasının son bulmasının ardından gerekli olan 15 gün içinde imha edilmemesi olmak üzere mevzuata iki kez aykırılık teşkil ettiğini tespit etmiştir. Bundan dolayı, başvuranın telefonlarının dinlenmesi yoluyla elde edilen bilgilerin, başvuran hakkında yürütülen disiplin soruşturması kapsamında kullanılması nedeniyle Sözleşme'nin 8. maddesinin ihlal edilmiş olduğuna karar vermiştir. Zira mahkeme özellikle hangi denetleme tedbirlerinin hangi şartlarda uygulanabileceğini belirten ve bu kapsamda disiplin soruşturmalarına değinilmeyen başta Anayasa’nın 22 ve CMK'nın 135. maddeleri olmak üzere iç hukukun ihlaline sebebiyet verildiğini gözlemlemektedir. Diğer bir ifade ile hukuka uygun verilerin disiplin soruşturmasında kullanılmasına imkan veren düzenleme olmaması nedeniyle bu verilerin disiplin soruşturması bakımından hukuka aykırı veri haline geldiğine hükmetmiştir.

\section{2-) Anayasa Mahkemesi'nin Hukuka Aykırı Delillere Bakış Açısı}

Anayasa’nın "Temel haklar ve ödevler" başlıklı ikinci kısmında düzenlenen 38/6. maddesinde yer alan "Kanuna aykur olarak elde edilmiş bulgular, delil olarak kabul edilemez" hükmü sadece ceza yargısında değil, hukuk yargısı ve idari yargıda da geçerlidir. Dolayısıyla da bu emredici

[62] İNCEOĞLU, Sibel, Adil Yargılanma Hakkı, İnsan Hakları Avrupa Sözleşmesi ve Anayasa, Beta Yayınları, İstanbul 2013, s.288; “...Delillerin kabul edilebilirliği”, öncelikle iç hukukun düzenleme alanına girer ve "delillerin değerlendirmesi" kural olarak ulusal mahkemelerin görevidir. Bireysel başvuru kapsamında Mahkemenin görevi, delillerin elde edilme yöntemi de dâhil yargılamanın bir bütün olarak adil olup olmadığını saptamaktır. (AİHM Ramanauskas/Litvanya Kararı, Başvuru No: 74420/01, K.T: 5/2/2008, Prg. 52).

[63] AİHM Karabeyoğlu/Türkiye Kararı, Başvuru No: 30083/10, K.T:07/06/2016 


\section{Dr. Bahattin ARAS}

hüküm hem ceza yargılamasında hem de disiplin hukuku yönünden yarg1 denetimi yapan idari yargılamada esas alınmak zorundadır. Anayasayı yorumlama konusunda tek yetkili mercii olan Anayasa Mahkemesi'nin Anayasa'nın 38. maddesinde idari ve adli cezalar arasında bir ayrım yapılmadığı belirtilerek disiplin cezalarının Anayasảnın 38. maddesi kapsamında olduğu yönündeki 1990/12 Esas, 1991/7 Karar ve 04.04.1991 Tarihli kararı da dikkate alındığında hukuka ve kanuna aykırı olarak elde edilmiş bulguların delil olarak kabul edilerek tek başına disiplin işlemine esas alınması mümkün değildir.

Anayasa Mahkemesi' nin hukuka aykırı şekilde elde edilmiş olan delillerin disiplin soruşturmalarında kullanılamayacağına ilişkin önemli kararları bulunmaktadır. Disiplin hukukunda hukuka aykırı delillerin soruşturmada kullanılamayacağı yönünde ilgili kanunlarda açık hüküm bulunmamasından kaynaklı olarak yerel mahkeme ve yüksek mahkemelerin farklı yönde kararları bulunmasına rağmen Anayasa Mahkemesi verdiği kararlarda bu eksikliği Anayasa’nın temel hak ve hürriyetlere ilişkin hükümleri ve ceza hukukunun temel ilkelerinin disiplin hukuku açısından da geçerli olduğuna ilişkin genel uygulaması ile çözüme kavuşturmuştur.

Anayasa Mahkemesi'nin 13.07.2016 tarih, 2014/7738 Başvuru Numaralı kararında, internet sitesinde yayımlanan ve başvurucuya ait olduğu iddia edilen cinsel içerikli ses kayıtlarının memurluk sıfatı ile bağdaşmayacak nitelikte ahlak dışı, yüz kızartıcı ve utanç verici eylem teşkil ettiği gerekçesiyle kişi hakkında verilmiş olan devlet memurluğundan çıkarma cezasına ilişkin olarak Anayasa’nın 20. maddesinde güvence altına alınan özel hayatın gizliliği hakkının ihlal edildiğine vurgu yaptıktan sonra “...soruşturmaya konu ses kayıtlarının hukuka aykırı şekilde dinlenerek kayda alındiğg ve manipülasyon yapılarak elde edildiği konusunda ileri sürülen iddialara ilişkin olarak bir araştırma yapılmadı̆̆g, hukuka aykırı delillerin yürütülen disiplin soruşturmasinda geçerli delil olarak kabul edilemeyeceği ve hukuka aykırı delillere dayanılarak işlem tesis edilemeyeceği hususunun gözetilmedi$\breve{g} i . . . "$ demek suretiyle hukuka aykırı delillerin disiplin soruşturmasında kullanılamayacağını açıkça belirtmiştir. ${ }^{[6]]}$ Görüldüğü üzere Mahkeme özel hayatın gizliliği ve özel hayata saygı hakkını ve Anayasa'nın 13. maddesinde düzenlenen temel hak ve özgürlüklerin sınırlama ölçütlerini dikkate alarak, ses kayıtlarının Anayasa'da yer alan hakların sınırlandırma ölçütlerini aşacak derecede ihlali vasıtasıyla ele geçirilmesinden ötürü hukuka aykırı

[64] AYM, İlknur Yüksel Kararı, Bireysel Başvuru No: 2014/7738, K.T:13.07.2016 
delil olarak değerlendirmiş ve özel hayatın gizliliği hakkının ihlal edildiğine hükmetmiştir. ${ }^{[65]}$

Mahkemenin bu kararında hukuka aykırı delillerin disiplin soruşturmasındaki durumuna ilişkin olarak ceza yargılaması hukuku ilkelerinin disiplin hukukunda uygulanabileceğinin yanı sıra Anayasa’nın 38. maddesinde düzenlenen kanuna aykırı elde edilen bulguların delil olarak kullanılamayacağına ilişkin düzenleme "Hakların Korunmasına İlişkin Hükümler" başlığı altında yer aldığından doğrudan disiplin soruşturmalarında da dikkate alınması gerektiği açıkça vurgulanmıştır.

Ancak Anayasa Mahkemesi son dönemde hukuka aykırı olarak elde edilen delillere ilişkin yapılan bazı bireysel başvurularda geçmiş içtihatlarındaki tespitler yerine Yargıtay'ın son dönem içtihatları doğrultusunda değerlendirmeler yapmaktadır. Mahkeme FETÖ/PDY yargılamaları kapsamında delil olarak kullanılan ByLock mesajlaşma programına ilişkin içeriklerin istihbarat çalışmaları sırasında rastlanan bir veri olduğu hususu tespit edilmesine karşın bu istihbari verilerin doğrudan ceza yargılamasında delil olarak kullanılması noktasında bir hukuka aykırılık bulunmadığına karar vermiştir ${ }^{[6]]}$ Halbuki bir başka kararında ${ }^{[67]}$ "... ilettişsimin denetlenmesi tedbiri şayet 5271 saynl Kanun'un 135. maddesinde yer alan suçlar kapsaminda mevzuatta öngörülen şekilde gerçekleştirilmişse, bu suretle elde edilen deliller hukuka uygundur ve bu delillere dayanılarak idari işlemler tesis edilebilir..." demesine karşın ByLock mesajlaşma programı ve içeriği 5271 sayılı Kanun'un 135 ve MİT Kanunu 6/2. maddelerine göre iletişimin denetlenmesi tedbiri kapsamında olmasına rağmen bu programa ilişkin kayıtların bu kanunlarda aranan koşullarda elde edilmeden ceza ve disiplin soruşturmasında kullanılmasını hukuka aykırı görmemiştir.

\section{3-) Danıştay'ın Hukuka Aykırı Delillere Bakış Açısı}

Pozitif hukuk kuralı bulunmamasından kaynaklı olarak hukuka aykırı elde edilmiş delillerin disiplin hukukunda kullanılamayacağı genel olarak kabul edilmekle birlikte, geçmişte bu delillerin kullanılabileceği yönünde bir kısım yargı kararları da bulunmaktaydı.

\footnotetext{
[65] Fİ̧ ÜSTÜN, s.31-32

[66] AYM Ferhat Kara Kararı, Başvuru No: 2018/15231, K.T: 4/6/2020, Prg.136

[67] AYM Muammer Yılmaz Kararı, Başvuru No: 2014/4779, K.T:14/11/2018, Prg.66
} 


\section{Dr. Bahattin ARAS}

Danıştay geçmiş bir kısım kararlarında ${ }^{[68]}$, disiplin hukukunun bağımsız olduğu, ceza soruşturmalarının disiplin soruşturmalarını bağlamadığı zikredilerek, hukuka aykırı delillerin disiplin soruşturmalarında kullanılmasına engel olmadığı yönünde hükümler tesis etmekteydi. Ancak, Danıştay yakın dönemlerde içtihat değişikliğine giderek, Anayasa'nın 38. maddesinde öngörülen hukuka aykırı elde edilen bulguların delil olarak kullanılmaması yönündeki ilkenin disiplin soruşturmalarında uygulanmas1 gerektiğine hükmetmiştir. ${ }^{[69]}$

Bu kapsamda Danıştay’ın yakın tarihli kararına konu bir olayda, İlçe Emniyet Müdürü olarak görev yapan davacının, "Gizli tutulması zorunlu olan ve görevi ile ilgili bulunan bilgi ve belgeleri görevli veya yetkili olmayan kişilere açıklamak" fiilini işlediğinden bahisle, meslekten çıkarma cezasıyla cezalandırılmasına ilişkin İçişleri Bakanlığı Yüksek Disiplin Kurulu kararının iptali istemiyle açılan davada, ilk derece mahkemesi, dosyada bulunan telefon kayıtlarına ilişkin dökümlerin incelenmesi neticesinde davacının, hakkında gizlilik kararı olan olay ile ilgili haber muhabirleri ile sürekli iletişim halinde olduğu, olay hakkında karşlıklı bilgi alışverişinin sağlandığı, Emniyet Teşkilatı Disiplin Tüzüğü’nün 8/13 maddesinde yer alan fiilin sübut bulduğu ve dava konusu işlemde hukuka aykırılık bulunmadığı gerekçesiyle davayı reddetmiştir.

Kararın temyizi üzerine Danıştay 5 . Dairesi ${ }^{[70]}$ ise Anayasa Mahkemesi'nin ceza hukukunun temel ilkelerinin disiplin hukuku açısından da geçerli olduğunu kabul ettiği 2014/100 Esas, 2015/6 Karar ve 14.1.2015 tarihli kararına atıfta bulunarak; disiplin cezası verilmesinde asıl delil olarak kullanılan telefon kayıtlarının Ceza Muhakemesi Kanunu'nun 135. maddesinde yer alan suçlar kapsamında bulunmayan bir fiile ilişkin olduğu ve bu fiile ilişkin ses kayıtlarının, tek başına delil olarak kullanılamayacağını ifade ettikten sonra, hukuka uygun olarak elde edilmiş başka delil ve belgeler olmaksizın sadece bu delillere dayanılarak disiplin cezası verilemeyeceğine hükmetmiştir. Danıştay bu kararı ile CMK'nın 135. maddesine aykırı olarak elde edilen telefon kayıtlarının disiplin cezasına gerekçe yapılamayacağını ortaya koymuştur. Diğer bir ifade ile hukuka aykırı elde edilen delillerin disiplin soruşturmasında kullanılamayacağına hükmetmiştir. ${ }^{[71]}$

[68] Danıştay 12. D., 2010/64 E., 2011/474 K., 04.02.2011 T.

[69] Fİ̧ ÜSTÜN, s. 17

[70] Danıştay 5.D., 2016/18730 E., 2017/21649 K., 25.10.2017 T.

[71] GÜNDÜZ, s.101 
Diğer taraftan delil yasakları, delil elde etme ve delil değerlendirme yasağı olmak üzere iki farklı başlık altında değerlendirilmektedir. Delillerin elde edilme şekline ilişkin yasaklara delil elde etme yasakları, hukuka uygun elde edilmiş olsa bile o delilin yargılamada ortaya konulup değerlendirilmesine ilişkin yasaklara ise delil değerlendirme yasakları denilmektedir. Danıştay verdiği bir kararda ${ }^{[72]}$ bu ayırımı çok net ortaya koymuştur .Danıştay ilgili kararında dava konusu meslekten çıkarma cezasına esas alınan davacıya isnat edilen fiillerin, büyük oranda davacı dışındaki üçüncü kişilerin telefon görüşmelerinin usulüne uygun olarak dinlenilmesi sonucu elde edilen tapelerden elde edildiğini tespit ettikten sonra mahkeme kararıyla gerçekleştirilen telekomünikasyon yoluyla yapılan iletişimin denetlenmesi sırasında elde edilen ses kayıtlarının, bu soruşturma veya kovuşturmayla ilgisi olmayan üçüncü kişiler hakkında yürütülecek disiplin soruşturmasında delil olarak kullanılamayacağı ve sadece bu delillere dayanılarak disiplin cezası verilemeyeceğine hükmetmiştir. İlgili kararda aşağıdaki tespit ve değerlendirmelere yer verilmiştir:

“...5271 saynl Ceza Mubakemesi Kanunu'nun "Tesadüfen elde edilen deliller" başlıkli 138. maddesinin 2. fikrasinda "Telekomünikasyon yoluyla yapulan iletişimin denetlenmesi sirasinda, yapılmakta olan soruşturma veya kovusturmayla ilgisi olmayan ve ancak 135 inci maddenin altıncı fikrasında sayılan suçlardan birinin işlendiği şüphesini uyandırabilecek bir delil elde edilirse; bu delil muhafaza altına alınır ve durum Cumburiyet Savcılı̆̆ına derhâl bildirilir." hükmüne yer verilmek ve Yargitay Ceza Genel Kurulu'nun E:2013/483, K2013/599 sayılı kararında "Maddi gerçeğin araştırılması aşamasinda kişisel ya da toplumsal değerlerin korunmast zorunludur. Bu değerlerin korunması amacıyla kanun koyucu delillerin serbestliği ilkesine delil yasakları olarak adlandirılan birtakım sinırlamalar getirmiştir. Delil yasakları delil elde etme ve delil değerlendirme yasağı olarak iki gruba ayrilmaktadır. Delillerin elde edilme şekline ilişkin yasaklara delil elde etme yasakları, hukuka uygun elde edilmiş olsa bile o delilin yargilamada ortaya konulup değerlendirilmesine ilişkin yasaklara ise delil değerlendirme yasaklar denilmektedir. CMK'nin telekomünikasyon yoluyla yapulan iletişimin denetlenmesi sirasinda elde edilen delillerin ayn Kanun'un 135. maddesinin altınc fikrasında saynlanlar dişında bir suçun soruşturma ve kovuşturulmasinda kullanılmaması ise delil değerlendirilmesi yasaklarına örnek olarak gösterilebilir. 5271 saynl CMK'nın 217. maddesinin ikinci fikrasinda yer alan; "Yüklenen suç, huku-

[72] Danıştay 16. D., , 2015/3643 E., 2015/6993 K., 11.11.2015 T. 


\section{Dr. Bahattin ARAS}

ka uygun bir şekilde elde edilmiş her türlü delille ispat edilebilir" şeklindeki düzenleme ile ayrica ceza muhakemesinde kullanulacak delillerin hukuka uygun şekilde elde edilmesi gerektiği belirtilmiştir. Ancak, 135. maddenin altınc fikrasinda sayılan suçlarla sinırl olmak kaydiyla aynı sorușturma veya kovuşturmayla ilgili suçlar yönüyle evleviyetle kullanılabileceğinin kabulü gerekir" denilmekle, 135. maddede sayılan suçlar için başlatılmış bir soruşturma veya kovuşturmada elde edilen delillerin 135. madde kapsamında olmayan suçlar için kullanılamayacağı kabul edilmiş olmaktadır.

Yukarıda yer verilen kanun hükümleri ve yargı kararlarının değerlendirilmesinden, telekomünikasyon yoluyla yapılan iletişimin denetlenmesi sirasinda elde edilen ses kayıtlarının, bu soruşturma veya kovuşturmayla ilgisi olmayan ü̧üncü kişiler hakkında yürütülecek disiplin sorușturmasında delil olarak kullanılamayacağı ve sadece bu delillere dayanularak disiplin cezası verilemeyeceği sonucuna ulaşılmaktadır.

Bu durumda, dava konusu disiplin cezasinın verilmesinde, davacinın özel hayatı kapsamındaki davranış ve ilişkilerinin belirleyici olduğu anlaşıldiğından, davacıya verilen meslekten çıkarma cezasının, Anayasänın 20. maddesi ve AIHS'nin 8. maddesinde tanımlanan özel hayatın gizlilïgi hakkına orantısız bir müdahale oluşturduğu ve bu yönüyle hukuka uygun olmadiğg sonucuna varlmasının yanısıra; "soruşturmada adı geçen suç örgütü lideri ve ïyesi kişilerin bir kısım adli işlerini takip etmek" ve "bahsi geçenlerin kendi işlerinde mesleki sifat ve konumunu kullanmalarnna müsaade etmek" gibi davacının mesleki hayatına ilişkin olan suçlamaların ise davacı aleyhine delil olarak kullanılamayacak olan tapeler dişında, her türlü şüpheden uzak, kesin ve somut delillerle kanıtlanamadiğından, davacıya verilen meslekten çıkarma cezasinda hukuka uyarlık bulunmamaktadır...".

Görüldüğü üzere Danıştay son uygulamaları çerçevesinde delil elde etme yasakları ve delil değerlendirme yasağı kapsamındaki herhangi bir veri veya delilin disiplin soruşturmasında kullanılması mümkün değildir. Tesadüfen elde edilen iletişim verilerinin disiplin soruşturmasında kullanılamayacağına da açıça vurgu yapılmıştır. 


\section{SONUÇ}

Ceza yargılamasının temel amacı maddi gerçeğin ortaya çıkarılması olduğu gibi disiplin soruşturmasının da temel gayesi maddi gerçeği ortaya çıkarmaktır. Kurumsal düzeni ve disiplini bozucu eylemde bulunduğu iddia olunan kamu görevlisi hakkında disiplin soruşturması yürütülürken anayasal ve yasal ilke ve esaslara uygun hareket edilmesi gerekir. Aksi takdirde disiplin soruşturmasında hukuka aykırı uygulamalar ortaya çıkar. Bu bağlamda disiplin soruşturmalarında ortaya çıkması muhtemel hukuka aykırılıklardan biri de hukuka aykırı delil elde edilmesi ve elde edilen hukuka aykırı delillerin disiplin soruşturmasında kullanılmasıdır. ${ }^{[73]}$

Anayasa Mahkemesi'nin de kararlarında vurguladığı ${ }^{[7]}$ üzere Anayasa’nın "Suç ve cezalara iliş̧kin esaslar" başlıklı 38. maddesinde idari ve adli cezalar arasında bir ayrım yapılmamıştır. Buna göre, Anayasa’nın bu hükmü hem idari hem de adli cezaları kapsadığından dolayı disiplin cezaları da Anayasảnın 38. maddesi kapsamındadır. Dolayısıyla hukuka aykırı delillerin yargılama hukukunda kullanılması yasağı ceza yargılamasında olduğu gibi disiplin soruşturmasında da aynen geçerlidir.

Ceza veya disiplin soruşturmasında maddi gerçeğin ortaya çıkarılması ancak hukuka uygun yöntemlerle elde edilmiş delillerle mümkündür. Maddi gerçeğin ortaya çıkarılması gerekçesiyle de olsa hukuka aykırı delillere dayanılamaz. Burada Anayasa'nın 38/6. maddesinden ve evrensel hukuk ilkelerinden kaynağını alan mutlak bir yasak vardır. Dolayısıyla somut olayın özellikleri, kamu yararının gerektirmesi gibi soyut ve içeriği kötüye kullanılabilecek, keyfi yorumlanabilecek gerekçelerle hukuka aykırı elde edilmiş delillerin disiplin hukukunda kullanılmasına istisna tanınması mümkün değildir. ${ }^{[75]}$

Diğer taraftan hukuk devleti ilkesinin bir gereği olarak yargılama esnasında devletin delil elde etme ve hukuka aykırı delilleri değerlendirmesi konusunda konulmuş sınırlar bulunmaktadır. İlkenin bir gereği olarak devletin kendisi hukuka aykırı delil elde etmesi söz konusu olmadığı gibi herhangi bir şekilde elde edilmiş hukuka aykırı delilleri meşrulaştırma veya yargısal sürece dahil etmesi de mümkün değildir. Dolayısıyla hukuk devleti ilkesine aykırı olarak, disiplin hukukunda her türlü delilin kabul edilmesi,

[73] Fiş ÜSTÜN, s. 18

[74] AYM, 1990/12 E., 1991/7 K., 04.04.1991 T.

[75] GÜNEŞ, s.112 


\section{Dr. Bahattin ARAS}

kişilerin hak ve hürriyetlerinin bertaraf edilmesinin yanı sıra idarenin keyfi ve hukuksuz davranışlarının da meşrulaştırılması demektir. ${ }^{[76]}$ Aynı şekilde disiplin soruşturmaları dâhil tüm soruşturma ve kovuşturmalarda adil yargılanma ilkesine uygun hareket edilmesi ve bu soruşturmalar bakımından kişiye tanınan güvencelerin ihlal edilmemesi gerekmektedir. Dolayısıyla hukuka aykırı delillerin yargılamada kullanılmaması, adil yargılanma hakkı kapsamında kişiye tanınmış olan yargılama güvencelerinden biridir.

Öte yandan, bir hukuk düzeninde hukuka aykırı olan delilin diğer bir hukuk düzeninde hukuka uygun kabul edilerek yargılamanın yapılması, hukuk devletine olan güveni sarsacaktır. ${ }^{[7]]} \mathrm{Bu}$ noktada kamu düzeni ve kamu yararı gibi soyut gerekçelerle bu delillerin disiplin soruşturmalarında kullanılmasına müsaade etmek disiplin işlemi gibi önemli bir işlemin keyfi ve baskı aracı olarak kullanılmasına neden olabileceğinden bu gibi soyut gerekçelerin hukuk devleti ilkesi ile bağdaşır tarafı yoktur. Aynı şekilde geçmiş bir kısım Danıştay kararlarında olduğu gibi bu tip hukuka aykırı delillerin "tek başına delil değerinin olmadığı" gerekçesiyle yan delillerle desteklenmek suretiyle onlara meşruiyet kazandırılması da mümkün değildir. Zira zehirli ağacın meyvesi zehirli olduğundan bu hukuka aykırılığın giderilme yolu bulunmamaktadır. Her türlü soruşturma yetkisine sahip idarenin hukuka uygun delillere ulaşıp sonuca gitmesi gerektiği düşüncesinin kamu idaresince kabul edilmesi gerekmektedir. Aksinin kabulü halinde idarenin hukuka aykırı delil elde etmesinin teşvik edileceği ve idarenin sahip olduğu imkânlar nedeniyle bunun çok kolay olacağı unutulmamalidır. ${ }^{[78]}$

[76] ATAY, s.106; GÜNEŞ, s. 104

[77] Fİ̧ ÜSTÜN, s.32

[78] CEYLAN, Mahmut, “Idari Yargıda Delil Serbestisi ve Sinırlar”, Karadeniz Teknik Üniversitesi Sosyal Bilimler Enstitüsü Sosyal Bilimler Dergisi, Y.8, Aralık 2018, S. 16, s.336; YASİN, Melikşah, İdari Yargılama Usulünde İspat, İstanbul 2015, s.62 


\section{KAYNAKÇA}

AKYILMAZ, Bahtiyar, "Anayasal Esaslar Çerçevesinde Kamu Personeli Disiplin Hukuku ve Uygulamadaki Sorunlar", Gazi Üniversitesi Hukuk Fakültesi Dergisi, Y. 2002, C. 6, S. 1-2, s.241-262.

AKYÜREK, Güçlü, "Ceza Yargılamasında Hukuka Aykırı Delillerin Değerlendirilmesi Sorunu”, Türkiye Barolar Birliği Dergisi, Y. 2012, S.101, s.61-82.

ARSLAN, Çetin, "Ceza Muhakemesinde İletişimin Denetlenmesi Yoluyla Elde Edilen Delillerin Disiplin Hukukundaki Durumu Üzerine Bir Değerlendirme”, Fasikül Hukuk Dergisi Y.2010, C.2, S.3, s.32-40.

ATAY, Ender Ethem, İdare Hukuku, Turhan Kitabevi, Ankara 2016.

AYDIN, Devrim, Ceza Muhakemesinde Deliller, Yetkin Yayınları, Ankara 2015.

BAŞ, Eylem, "Hâkimlerin ve Savcıların Disiplin Yönünden Soruşturulmaları ve Issledikleri Suçlar Nedeniyle Yargılanmaları”, Ankara Barosu Dergisi, Y.2016, S.3, s.265-360.

BAŞLAR, Yusuf "Elektronik Delil Ve Ceza Yargılamasında Kabul Edilebilirliğine İliskkin Bir Inceleme” Legal Hukuk Dergisi, Y.2018, S.184, C.16, s.1655-1688.

CANOĞLU, Veysel Candan, "Disiplin Soruşturmasında Delil ve İspat" Türkiye Barolar Birliği Dergisi, Y.2018, S.138, s.231-272.

CEM, Cemil, "Disiplin ve Disiplin Hukuku”, Ankara Barosu Dergisi, Y.1969, S.5, s.821-834. CENTEL, Nur/ ZAFER, Hamide, Ceza Muhakemesi Hukuku, Beta Yayıncılık, İstanbul 2020.

CEYLAN, Mahmut, "Iddari Yargıda Delil Serbestisi ve Sınırları", Karadeniz Teknik Üniversitesi Sosyal Bilimler Enstitüsü Sosyal Bilimler Dergisi, Y.8, Aralık 2018, S. 16, s.325-341.

ÇAKMAK, Seyfullah, "İletişimin Denetlenmesi Koruma Tedbiri Çerçevesinde Elde Edilen Tesadüfi Delillerin Disiplin Soruşturmasinda Kullanılması", Terazi Hukuk Dergisi, Y.2010, C.5, S.48, s.71-86.

ÇINAR, Ali Rıza, "Hukuka Aykırı Kanıtlar", Türkiye Barolar Birliği Dergisi, Y. 2004, S. 55, s.31-64. 


\section{Dr. Bahattin ARAS}

DEMİR, Nazlı Hilal, Yasak Deliller ve İnsan Onuru, İstanbul Kültür Üniversitesi Sosyal Bilimler Enstitüsü Yayınlanmamış Yüksek Lisans Tezi, İstanbul 2012.

ERMAN, Sahir, Hukuka Aykırı Deliller, İstanbul Barosu Yayınları, İstanbul 1995.

Fİş ÜSTÜN, Gül, "Disiplin Soruşturmalarında Hukuka Aykırı Deliller", Marmara Üniversitesi Hukuk Fakültesi Hukuk Araştırmaları Dergisi, Y.2018, C.24, S.1, s.17-35

GÖKPINAR, Mahmut, Disiplin Hukukunda Yasak Hukuka Aykırı Deliller, Disiplin Suçu Teorisi, Kazancı Hukuk Yayınevi, İstanbul 2011.

GÜNDÜZ, Fatma Ebru, "Hukuka Aykırı Elde Edilmiş Delillerin Disiplin Hukukunda Kullanılması", Yıldırım Beyazıt Hukuk Dergisi, Y.4, S. 2019/1, s.89-114.

İNCEOĞLU, Sibel, Adil Yargılanma Hakkı, İnsan Hakları Avrupa Sözleşmesi ve Anayasa, Beta Yayınları, İstanbul 2013.

İPEK, Ali İhsan, "İletişsimin Denetlenmesi Yoluyla Elde Edilen Delillerin Disiplin Hukukuna Etkisi", TAAD, Y.2, Ekim 2011, C.1, S.7, s.221-256.

KAYMAZ, Seydi, Ceza Muhakemesinde Telekomünikasyon Yoluyla Yapılan İletişimin Denetlenmesi, Seçkin Yayıncılık, Ankara 2011.

ÖZBEK, Veli Özer/ DOĞAN, Koray, BACAKSIZ, Pınar, Ceza Muhakemesi Hukuku, 8. Baskı, Seçkin Yayınları, Ankara 2020.

ÖZTUNÇ, Özgün, "Ceza Muhakemesi Açısından Yasak Deliller ve Disiplin Soruşturması Açısından Yasak Deliller ile Tesadüfen Elde Edilen Delillerin Değerlendirilmesi", s.3, http://www.ozgunlaw.com/Uploads/imagel files/Makale22072011 DrOzgunOztunc.pdf, İET:29.12.2019.

ÖZTÜRK, Bahri, Nazari ve Uygulamalı Ceza Muhakemesi Hukuku, Seçkin Yayıncılık, Ankara 2020.

PINAR, İbrahim, Açıklamalı-İçtihatlı Memur Suçlarında İdari Soruşturma, Seçkin Yayıncılık, Ankara 1987.

SANCAKDAR, Oğuz/ TEPE, İlker, "Alman Federal Disiplin Kanunu ve İdari Disiplin Sorusturmalarmın Temel Esasları", İstanbul Üniversitesi Hukuk Fakültesi Mecmuası, Y.2011, C.69, S.1-2, s.251-272. 
ŞAHİN, Cihan, "Hâkim ve Cumburiyet Savcıları İle HSYK ve Yargitay Üyelerinin İletişimlerinin Denetlenmesi", TAAD, Y.3, Temmuz 2012, S.10, s.586-569-610.

ŞAHINN,Cumhur/GÖKTÜRK,Neslihan, Ceza Muhakemesi Hukuku II, 11. Baskı, Seçkin Yayınları, Ankara 2021.

ŞEN, Ersan, "İletişimin Dinlenmesi Tedbiri", Ceza Hukuku Dergisi, Ağustos 2007, s.97-135.

TANRIVER, Süha, "Türk Medeni Usul Hukuku Bağlamında Hukuka Aykır Yollardan Elde Edilen Delillerin İrdelenmesi”, Türkiye Barolar Birliği Dergisi, Y.2006, S.65, s.368-377.

TAŞKIN, Mustafa, Adli ve İstihbari Amaçlı İletişimin Denetlenmesi, Seçkin Yayıncılık, Ankara 2008.

TAŞTAN, Mehmet, "Telekomünikasyon Yoluyla Gerçekleştirilen İletişimin Önleme Amaçl Olarak Denetlenmesinin Amaç Kapsam ve Sinırları", Terazi Aylık Hukuk Dergisi, Y. 4, Ocak 2009, S.29, s.93-109.

TURHAN, Faruk/AKSU, Muharrem, "Insan Haklarmmn Korunması Açısından Önleyici Amaçl İletişsimin Denetlenmesi Tedbiri”, Uluslararas1 Davras Kongresi, Küresel Dialog, 24-27 Eylül 2009, ekitap, Isparta, s.2202-2226.

YASİN, Melikşah, İdari Yargılama Usulünde İspat, On İki Levha Yayıncılık, İstanbul 2015.

YAYLAK, Cihan, İdari Yargılama Usulünde Hukuka Aykırı Delillerin Değerlendirilmesi, On İki Levha Yayıncılık, İstanbul 2018.

YENISEY, Feridun/ NUHOĞLU, Ayşe, Ceza Muhakemesi Hukuku. Seçkin Yayınları, Ankara 2020.

YENİSEY, Feridun/ALTUNÇ, Sinan, "İletişimin Dinlenmesi Hakkında", http://www.turkhukuksitesi.com/showthread.php?t=15125, İET: 01/03/2020. 